\title{
Synthesis of Radioiodinated Carbocyclic Cytosine Analogues
}

\author{
Hyunseok Ahn, ${ }^{\dagger}$ Gwangil An, ${ }^{\star}$ and Hakjune Rhee ${ }^{\dagger, \S, *}$ \\ ${ }^{\dagger}$ Department of Bionanotechnology, Hanyang University, Kyunggi-do 426-791 Korea. ${ }^{*}$ E-mail: hrhee@hanyang.ac.kr \\ Laboratory of Radiopharmaceuticals and Laboratory of Nuclear Medicine, Seoul 139-706, Korea \\ $\S$ Department of Chemistry and Applied Chemistry, Hanyang University, Kyunggi-do 426-791 Korea \\ Received March 29, 2011, Accepted April 21, 2011
}

\begin{abstract}
The synthesis of carbocyclic analogues of normal nucleosides has grown exclusively since they have shown potential antiviral and antitumor activities. Radiolabeled cis-1-[4-(hydroxy-methyl)-cyclopent-2-enyl]-5-[ $\left.{ }^{124} \mathrm{I}\right]-$ iodocytosine (carbocyclic d4IC) and cis-1-[4-(hydroxy-methyl)-cyclopent-2-enyl]-5-(2-[ $\left.{ }^{124} \mathrm{I}\right]$ iodovinyl)cytosine (carbocyclic d4IVC) were synthesized. The synthetic route employed $\mathrm{Pd}(0)$-catalyzed coupling reaction together with organotin and exchange reaction for radioiodination as key reactions. Carbocyclic $\left[{ }^{124} \mathrm{I}\right] \mathrm{d} 4 \mathrm{IC}$ gave more than $75 \%$ radiochemical yield with greater than $95 \%$ radiochemical purity. Carbocyclic $\left[{ }^{124} \mathrm{I}\right] \mathrm{d} 4 \mathrm{IVC}$ gave more than $80 \%$ radiochemical yield with greater than $95 \%$ radiochemical purity.
\end{abstract}

Key Words : Carbocyclic nucleoside, Radioiodine, PET, Radiopharmaceutical, Labeling

\section{Introduction}

Herpes Simplex Virus type-1 thymidine kinase (HSV1-tk) is widely studied for the imaging of gene expression. ${ }^{1}$ Various radiolabeled nucleoside analogues, both pyrimidine and acycloguanosine derivatives, have been synthesized and evaluated for HSV1-tk imaging. ${ }^{2}$ Normal nucleoside analogues have lesser metabolic stability. The glycosidic linkage in normal nucleosides is cleaved by thymidine phosphorylase enzymes. ${ }^{3}$ The replacement of furanose oxygen by carbon gives the nucleoside greater stability in vivo. Because of this metabolic stability, carbocyclic nucleosides and their analogues have been investigated by many research groups. ${ }^{4,5}$ Recently, our group reported synthesis and biological evaluation of uracil based radioiodinated carbocyclic nucleosides, cis-1-[4-(hydroxymethyl)-cyclopent-2-enyl]-5$\left[{ }^{124} I\right]$ iodouracil (carbocyclic d4IU, 1) and cis-1-[4-(hydroxymethyl)-cyclopent-2-enyl]-5-(2-[ ${ }^{124}$ I] iodovinyl)uracil (carbocyclic d4IVU, 2) (Figure 1). ${ }^{6}$ Since the previous result showed the radioiodine labeled carbocyclic d4IU (1) and d4IVU (2) are potent imaging materials for HSV1-tk, we decided to extend our research to synthesize cytosine-based
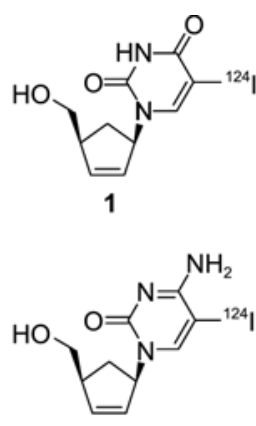

3
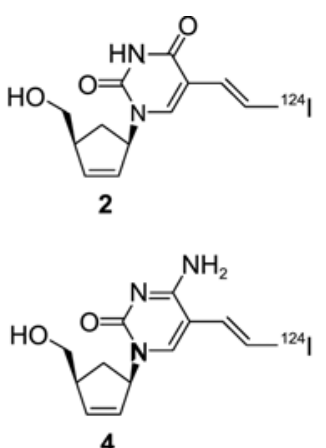

Figure 1. Carbocyclic $\left[{ }^{124} \mathrm{I}\right] \mathrm{d} 4 \mathrm{IU}$ (1), $\left[{ }^{124} \mathrm{I}\right] \mathrm{d} 4 \mathrm{IVU}(\mathbf{2}),\left[{ }^{124} \mathrm{I}\right] \mathrm{d} 4 \mathrm{IC}$ (3) and $\left[{ }^{124} \mathrm{I}\right] \mathrm{d} 4 \mathrm{IVC}(\mathbf{4})$. carbocyclic nucleosides. Here, we report the synthesis of cytosine-based radiolabeled carbocylic nucleosides, cis-1-[4(hydroxymethyl)-cyclopent-2-enyl]-5-[ $\left.{ }^{124} I\right]$ iodocytosine (carbocyclic d4IC, 3) and cis-1-[4-(hydroxymethyl)-cyclopent-2enyl]-5-(2-[ $\left[{ }^{124}\right.$ I] iodovinyl)cytosine (carbocyclic d4IVC, 4) as potential HSV1-tk imaging reporter probes (Figure 1).

\section{Results and Discussion}

In recent years, our group has synthesized carbocylic nucleosides and their analogues. ${ }^{5-7}$ We have prepared dicarbonate 10 (Scheme 1) as a key intermediate. In this paper, we used this dicarbonate $\mathbf{1 0}$ again to synthesize new carbocyclic nucleosides. Synthesis of the dicarbonate $\mathbf{1 0}$ was carried out using known procedures with a minor modification. For the ring-opening step of hydroxylactone $\mathbf{7}$ to triol $\mathbf{8}$, sodium borohydride was used. ${ }^{8}$ This method has an advantage in having a simpler and faster work-up than when using lithium aluminumhydride. ${ }^{5}$

Compounds 10 and 5-iodocytosine (11) were coupled by a

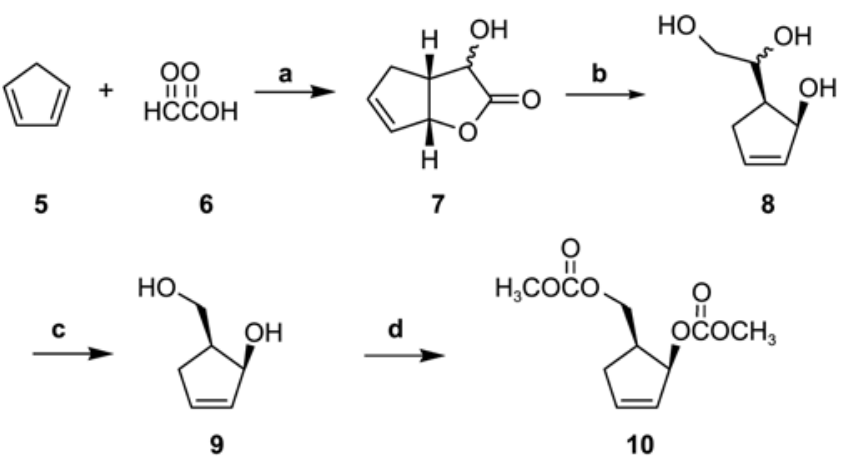

Scheme 1. (a) Toluene, $\mathrm{H}_{2} \mathrm{O}$, rt, $12 \mathrm{~h}, 40 \%$ (b) $\mathrm{NaBH}_{4}, \mathrm{CH}_{3} \mathrm{OH}$, rt, $1 \mathrm{~h}, 90 \%$. (c) (i) $\mathrm{NaIO}_{4}$, diethyl ether, $\mathrm{H}_{2} \mathrm{O}, \mathrm{rt}, 2 \mathrm{~h}$ (ii) ethylene glycol, rt, $1 \mathrm{~h}$ (iii) $\mathrm{NaBH}_{4}, \mathrm{rt}, 2 \mathrm{~h}, 70 \%$. (d) methyl chloroformate, DMAP, $\mathrm{CHCl}_{3}$, pyridine, $0^{\circ} \mathrm{C}, 1 \mathrm{~h}, 93 \%$. 
<smiles>CC(=O)OCC1C=CCC1COC(C)=O</smiles>

10<smiles>Nc1nc(=O)[nH]cc1I</smiles>

11<smiles></smiles><smiles>Nc1nc(=O)n(C2CC3C=CC2C3)cc1I</smiles>

14

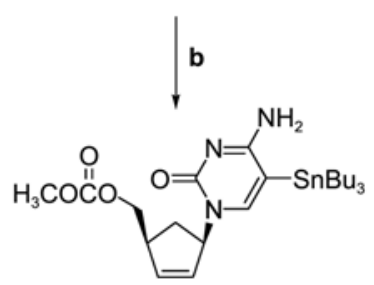

Scheme 2. (a) (i) $\mathrm{Pd}(\mathrm{OAc})_{2},(i-\mathrm{PrO})_{3} \mathrm{P}$, THF, under argon, rt (ii) $n$-BuLi, hexane, rt. (iii) $\mathbf{1 1}$ and $\mathrm{NaH}$ in DMSO (iv) $\mathbf{1 0}$ in anhydrous THF, 12 h, 70\%. (b) (i) $\mathrm{Pd}_{2}(\mathrm{dba})_{3}$, DMF (ii) bis(tributyltin), $100{ }^{\circ} \mathrm{C}, 7 \mathrm{~h}, 47 \%$. (c) (i) $0.5 \mathrm{~N}$ aqueous $\mathrm{K}_{2} \mathrm{CO}_{3}$, rt, $12 \mathrm{~h}$ (ii) $1.0 \mathrm{~N} \mathrm{HCl}$ to $\mathrm{pH} 7.0,71 \%$.

$\operatorname{Pd}(0)$-catalyzed Tsuji-Trost cross-coupling reaction. ${ }^{9}$ The $\mathrm{Pd}(0)$ catalyst was prepared in situ using $\mathrm{Pd}(\mathrm{OAc})_{2}$ in $\mathrm{THF}$ with triisopropyl phosphite and $n$-BuLi. The produced $\pi$ allylpalladium complex of compound 10 undergoes nucleophilic attack by the anion on the pyrimidine base 11..$^{5-7}$ Radiolabeling reactions with organotin compounds have been reported as a facile strategy. ${ }^{6,10}$ Thus, we applied this method for our synthesis. Compound $\mathbf{1 2}$ was converted to the desired stannylated precursor 13 by the $\operatorname{Pd}(0)$-catalyzed condensation of bis(tributyltin). ${ }^{6}$ In addition, compound $\mathbf{1 2}$ was hydrolyzed to produce cis-1-[4-(hydroxylmethyl)-2cyclopenten-1-yl]-5-iodocytosine (14) as a cold form of the reference compound.

For synthesis of the iodovinyl compound, a trialkylsilylvinyl precursor was selected. ${ }^{7,11}$ Compound 12 was converted to a trimethylsilylvinyl compound 15 by using a $\operatorname{Pd}(0)$ catalyzed Stille coupling reaction. ${ }^{7,12}$ After the hydrolysis of compound $\mathbf{1 5}$ and the following exchange reaction of compound 16 with $\mathrm{ICl}$, compound $\mathbf{1 7}$ was obtained as a cold form of reference material. ${ }^{7}$

As shown in Scheme 4, the radioiodination of 13 was performed using a no-carrier-added iodine-124 produced by the Korea Institute of Radiological and Medical Sciences (KIRAMS). Labeled compound 18 was hydrolyzed by $0.5 \mathrm{~N}$<smiles>CC(=O)OCC1C=CC2CC1C2</smiles>

12

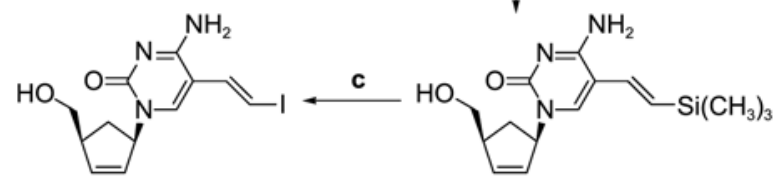

17

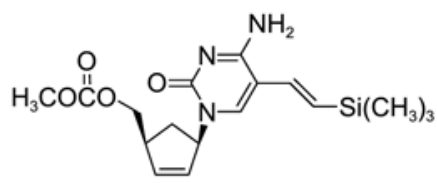

15

16
Scheme 3. (a) (E)-Buㄱ $\mathrm{SnCH}=\mathrm{CHSiMe}_{3}, \mathrm{Pd}_{2}(\mathrm{dba})_{3}$, DMF, $12 \mathrm{~h}, 60$ ${ }^{\circ} \mathrm{C}, 60 \%$. (b) (i) $0.5 \mathrm{~N}$ aqueous $\mathrm{K}_{2} \mathrm{CO}_{3}$, rt, $12 \mathrm{~h}$ (ii) $1.0 \mathrm{~N} \mathrm{HCl}, 93 \%$. (c) $\mathrm{ICl}, \mathrm{CH}_{3} \mathrm{CN}, 30 \mathrm{~min}, 70 \%$.

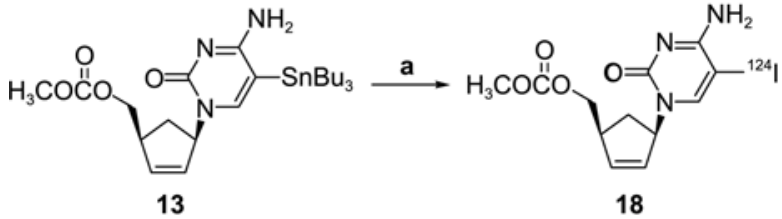

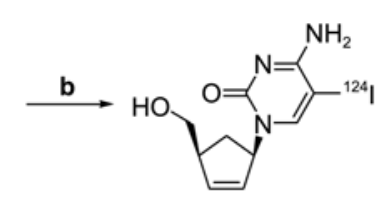

13

Scheme 4. (a) (i) $\mathrm{Na}^{124} \mathrm{I}, 0.01 \mathrm{~N} \mathrm{NaOH}, \mathrm{MeOH}$ (ii) $1.0 \mathrm{~N} \mathrm{HCl}$ to $\mathrm{pH}$ 4.0, $30 \% \mathrm{H}_{2} \mathrm{O}_{2}, 10 \min$ (iii) $\mathrm{NaHSO}_{3}$. (b) (i) $1.0 \mathrm{~N} \mathrm{~K}_{2} \mathrm{CO}_{3}, \mathrm{rt}, 1 \mathrm{~h}$ (ii) $1.0 \mathrm{~N} \mathrm{HCl}$ to $\mathrm{pH} 7$.

potassium carbonate. Then the desired carbocyclic d4IC (3) was separated, collected, and analyzed using reverse phase HPLC with UV and radioactivity detectors. The HPLC chromatographic retention time of carbocyclic d4IC (3) was 19.65 min with a radiochemical yield $>75 \%$ and radiochemical purity $>95 \%$. We confirmed that no side products were produced except for the unreacted radioiodide based on radio-TLC monitoring. Moreover, radiolabeled and reference compounds have the same retention time in HPLC.

With the same method, compound $\mathbf{1 6}$ was radioiodinated, separated, collected, and analyzed using reverse phase HPLC with UV and radioactivity detectors. The HPLC chromatographic retention time of carbocyclic d4IVC (4) was 17.0 min with a radiochemical yield $>80 \%$ and radiochemical purity $>95 \%$.

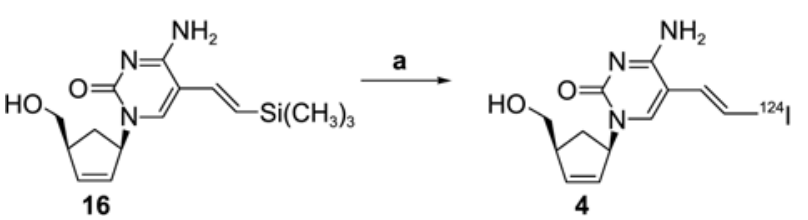

Scheme 5. (a) (i) $\mathrm{Na}^{124} \mathrm{I}, 0.01 \mathrm{~N} \mathrm{NaOH}, \mathrm{MeOH}$ (ii) $1.0 \mathrm{~N} \mathrm{HCl}$ to $\mathrm{pH}$ $4.0,30 \% \mathrm{H}_{2} \mathrm{O}_{2}, 10 \mathrm{~min}$ (iii) $\mathrm{NaHSO}_{3}$. 


\section{Conclusions}

We successfully synthesized radioiodinated cis-1-[4-(hydroxymethyl)-cyclopent-2-enyl]-5-[ $\left.{ }^{124} \mathrm{I}\right]$ iodocytosine (carbocyclic d4IC, 3) and cis-1-[4-(hydroxymethyl)-cyclopent-2enyl]-5-(2-[ ${ }^{124}$ I] iodovinyl)cytosine (carbocyclic d4IVC, 4). The biological evaluation of these compounds will be reported in due course.

\section{Experimental}

General. ${ }^{1} \mathrm{H}$ and ${ }^{13} \mathrm{C}$ NMR spectra were obtained using a Bruker 300 spectrometer (300 MHz) and a Varian 500 spectrometer $(500 \mathrm{MHz})$. Infrared spectra were recorded on a Bruker Alpha FT-IR spectrometer. Uncorrected melting points were determined with a Sanyo Gallenkamp melting point apparatus. HRMS were obtained with a JMS 700 spectrometer. Analytical thin layer chromatography (TLC) was conducted on E. Merck 60 F254 aluminum-backed silica-gel plates $(0.2 \mathrm{~mm})$ with a fluorescent indicator. Radio-TLC was measured with a Bioscan AC-3000 scanner (Washington D.C.). High performance liquid chromatography (HPLC) was carried out on a $\mu$ Bondapak $\mathrm{C} 18$ column $(7.8 \times 300 \mathrm{~mm}$, Waters $)$. Developed plates were visualized with UV light or a $2.0 \%$ phosphomolybdic acid staining solution. Flash column chromatography was performed using Merck silica-gel 60 (230-400 mesh) under positive pressure. All reagents and solvents were reagent grade and purified by known procedures before use. For radioiodine labeling, no-carrier-added iodine-124 was produced via the ${ }^{125} \mathrm{Te}(\mathrm{p}, 2 \mathrm{n}){ }^{124} \mathrm{I}$ nuclear reaction in an enriched ${ }^{125} \mathrm{TeO}_{2}$ at the KIRAMS MC-50 cyclotron.

5-(1,2-Dihydroxyethyl)-2-cyclopentenol (8). ${ }^{5}$ Sodium borohydride $(17.0 \mathrm{~g}, 450 \mathrm{mmol})$ was slowly added to a solution of $7(21.0 \mathrm{~g}, 150 \mathrm{mmol})$ in anhydrous methanol (1.0 $\mathrm{L}$ ) in an ice bath. After stirring the resulting solution for $1 \mathrm{~h}$ at ambient temperature, the solvent was removed by rotaryevaporation. The residue was diluted with water and neutralized with $1.0 \mathrm{~N}$ aqueous $\mathrm{HCl}$ to reach a $\mathrm{pH}$ of 7 . The aqueous solution was concentrated by rotary-evaporation. The residue was diluted with ethyl acetate, dried with anhydrous $\mathrm{MgSO}_{4}$, and concentrated by rotary-evaporation. The crude mixture was purified by silica-gel column chromatography $\left(\mathrm{CH}_{2} \mathrm{Cl}_{2}: \mathrm{MeOH}=7: 1, \mathrm{v} / \mathrm{v}\right)$ to give coloress oil $8\left(R_{f}\right.$ $=0.25 ; 15.1 \mathrm{~g}, 70 \%) .{ }^{1} \mathrm{H} \mathrm{NMR}\left(\mathrm{CDCl}_{3}\right) \delta 6.05(\mathrm{dd}, J=6.0$, $3.3 \mathrm{~Hz}, 1 \mathrm{H}), 5.84(\mathrm{dd}, J=5.4,1.8 \mathrm{~Hz}, 1 \mathrm{H}), 4.75(\mathrm{~m}, 1 \mathrm{H})$, $4.25(\mathrm{~m}, 1 \mathrm{H}), 4.11(\mathrm{~m}, 1 \mathrm{H}), 3.98(\mathrm{~m}, 1 \mathrm{H}), 3.78$ (br s, 3H), $2.58(\mathrm{~m}, 1 \mathrm{H}), 2.30(\mathrm{~m}, 2 \mathrm{H})$.

cis-1-[4-(Methoxycarbonyloxymethyl)-2-cyclopenten1-yl]-5-iodocytosine (12). Tri-isopropyl phosphite $(0.42$ $\mathrm{mL}, 1.74 \mathrm{mmol})$ was added to a solution of $\mathrm{Pd}(\mathrm{OAc})_{2}(0.098$ $\mathrm{g}, 0.434 \mathrm{mmol}$ ) at ambient temperature in anhydrous THF $(8.0 \mathrm{~mL})$ under argon. After stirring this solution for $5 \mathrm{~min}$, $n$-BuLi (1.6 $N$ in hexane, $0.54 \mathrm{~mL}, 0.868 \mathrm{mmol}$ ) was added at ambient temperature. The resulting mixture was stirred for 5 min to obtain the tetrakis(triisopropylphosphite) palladium(0) catalyst. The in situ prepared $\operatorname{Pd}(0)$ catalyst was added to a solution of 5-iodocytosine (11) $(1.24 \mathrm{~g}, 5.2 \mathrm{mmol})$ and sodium hydride $(0.208 \mathrm{~g}, 5.2 \mathrm{mmol})$ in anhydrous DMSO $(16.0 \mathrm{~mL})$ via cannula at ambient temperature. Next, a solution of dicarbonate $\mathbf{1 0}(1.0 \mathrm{~g}, 4.34 \mathrm{mmol})$ in anhydrous THF $(8.0 \mathrm{~mL})$ was added to the reaction mixture. After stirring for $2 \mathrm{~h}$, the reaction mixture was diluted with $\mathrm{CHCl}_{3}$ $(20 \mathrm{~mL})$ and washed with a brine solution $(20 \mathrm{~mL} \times 3)$. The aqueous phase was extracted with $\mathrm{CHCl}_{3}(20 \mathrm{~mL} \times 2)$. The organic phase was collected, dried with anhydrous $\mathrm{MgSO}_{4}$, and concentrated by rotary-evaporation. The residue was purified by silica-gel column chromatography $\left(\mathrm{CHCl}_{3}: \mathrm{MeOH}\right.$ $=20: 1, \mathrm{v} / \mathrm{v})$ to give a white solid $12\left(R_{f}=0.15 ; 1.19 \mathrm{~g}, 70 \%\right)$. mp $180{ }^{\circ} \mathrm{C}$; IR (thin film): 3456, 3062, 2995, 2950, 1748, 1714, 1649, 1622, 1478, 1281, $957 \mathrm{~cm}^{-1}$; ${ }^{1} \mathrm{H}$ NMR (DMSOd6) $\delta 7.69$ (br s, 1H), $7.61(\mathrm{~s}, 1 \mathrm{H}), 6.51(\mathrm{br} \mathrm{s}, 1 \mathrm{H}), 6.05(\mathrm{~m}$, $1 \mathrm{H}), 5.79(\mathrm{~m}, 1 \mathrm{H}), 5.50(\mathrm{~m}, 1 \mathrm{H}), 4.21-4.07(\mathrm{~m}, 2 \mathrm{H}), 3.70$ $(\mathrm{s}, 3 \mathrm{H}), 3.03(\mathrm{~m}, 1 \mathrm{H}), 2.60(\mathrm{~m}, 1 \mathrm{H}), 1.30(\mathrm{~m}, 1 \mathrm{H}) ;{ }^{13} \mathrm{C} \mathrm{NMR}$ (DMSO- $d_{6}$ ) $\delta 164.10,155.66,154.97,148.44,137.65,131.72$, 69.90, 62.02, 56.70, 55.09, 44.30, 34.23; HRMS: calculated for $\mathrm{C}_{12} \mathrm{H}_{14} \mathrm{IN}_{3} \mathrm{O}_{4}\left[\mathrm{M}^{+}, \mathrm{FAB}\right]$ 392.0107, found 392.0108.

cis-1-[4-(Methoxycarbonyloxymethyl)-2-cyclopenten1-yl]-5-tributylstannylcytosine (13). Bis(tributyltin) (0.4 $\mathrm{mL}, 0.75 \mathrm{mmol})$ and $\mathrm{Pd}_{2}(\mathrm{dba})_{3}(0.023 \mathrm{~g}, 0.025 \mathrm{mmol})$ were added to a solution of compound $12(0.20 \mathrm{~g}, 0.5 \mathrm{mmol})$ in anhydrous DMF $(10 \mathrm{~mL})$ at ambient temperature. The reaction mixture was stirred at $60{ }^{\circ} \mathrm{C}$ for $12 \mathrm{~h}$. After removal of the solvent by rotary-evaporation, the residue was diluted with methanol $(10 \mathrm{~mL})$. Silica-gel $(2.0 \mathrm{~g})$ was added to the solution, and the resulting suspension was dried under reduced pressure. A pale yellow gummy solid $\mathbf{1 3}\left(R_{f}=0.27\right.$; $0.155 \mathrm{~g}, 47 \%$ ) was obtained from preloaded silica-gel column chromatography $\left(\mathrm{CH}_{2} \mathrm{Cl}_{2}: \mathrm{MeOH}=20: 1, \mathrm{v} / \mathrm{v}\right)$. IR (thin film): 3454, 3005, 2970, 2956, 2872, 1739, 1366, 1228, 1217, 528 $\mathrm{cm}^{-1} ;{ }^{1} \mathrm{H} \mathrm{NMR}\left(\mathrm{CDCl}_{3}\right) \delta 7.11(\mathrm{~s}, 1 \mathrm{H}), 6.08(\mathrm{~m}, 1 \mathrm{H}), 5.83(\mathrm{~s}$, $1 \mathrm{H}), 5.74(\mathrm{~m}, 1 \mathrm{H}), 4.18-4.06(\mathrm{~m} .2 \mathrm{H}), 3.77(\mathrm{~s}, 3 \mathrm{H}), 3.10(\mathrm{~m}$, $1 \mathrm{H}), 2.82(\mathrm{~m}, 1 \mathrm{H}), 1.54-1.46(\mathrm{~m}, 6 \mathrm{H}), 1.36-1.29(\mathrm{~m}, 7 \mathrm{H})$, 1.13-1.02 (m, 6H), 0.93-0.88 (m, 9H); ${ }^{13} \mathrm{C} \mathrm{NMR}\left(\mathrm{CDCl}_{3}\right) \delta$ $169.76,156.87,155.74,147.33,136.78,131.85,100.90$, 70.12, 61.46, 54.82, 44.02, 34.67, 28.93, 27.21, 13.66, 9.68; HRMS: calculated for $\mathrm{C}_{24} \mathrm{H}_{43} \mathrm{~N}_{3} \mathrm{O}_{4} \mathrm{Sn}\left[\mathrm{M}^{+}, \mathrm{FAB}\right] 556.2202$, found 556.2200.

cis-1-[4-(Hydroxymethyl)-2-cyclopenten-1-yl]-5-iodocytosine (14) Compound $12(0.20 \mathrm{~g}, 0.511 \mathrm{mmol})$ was added to $0.5 \mathrm{~N}$ aqueous potassium carbonate $(10.0 \mathrm{~mL})$ and stirred at room temperature for $12 \mathrm{~h}$. The reaction mixture was neutralized to $\mathrm{pH} 7-8$ with $1.0 \mathrm{~N} \mathrm{HCl}$. After removal of the solvent by rotary-evaporation, the residue was diluted with methanol $(10 \mathrm{~mL})$. Silica-gel $(2.0 \mathrm{~g})$ was added to the solution, and the resulting suspension was dried under reduced pressure. A white solid $14\left(R_{f}=0.14 ; 0.155 \mathrm{~g}, 91 \%\right)$ was obtained from preloaded silica-gel column chromatography $\left(\mathrm{CH}_{2} \mathrm{Cl}_{2}: \mathrm{MeOH}=20: 1\right.$ to $15: 1$, v/v). mp $192{ }^{\circ} \mathrm{C}$; IR (thin film): 3423, 2940, 2872, 1632, 1596, $1484 \mathrm{~cm}^{-1} ;{ }^{1} \mathrm{H}$ NMR (DMSO- $\left.d_{6}\right) \delta 7.79(\mathrm{~s}, 1 \mathrm{H}), 7.68$ (br s, 1H), 6.48 (br s, $1 \mathrm{H}), 6.80(\mathrm{~m}, 1 \mathrm{H}), 5.69(\mathrm{~m}, 1 \mathrm{H}), 5.50(\mathrm{~m}, 1 \mathrm{H}), 4.75(\mathrm{~m}, 1 \mathrm{H})$, 3.52-3.35 (m, 2H), $2.79(\mathrm{~m}, 1 \mathrm{H}), 2.49(\mathrm{~m}, 1 \mathrm{H}), 1.32(\mathrm{~m}, 1 \mathrm{H})$; ${ }^{13} \mathrm{C}$ NMR (DMSO- $\left.d_{6}\right) \delta 163.99,155.00,148.95,139.97$, 130.60, 63.69, 61.82, 56.31, 47.71, 34.03; HRMS: calculated 
for $\mathrm{C}_{10} \mathrm{H}_{13} \mathrm{~N}_{3} \mathrm{O}_{2} \mathrm{I}\left[\mathrm{M}^{+}, \mathrm{FAB}\right] 334.0053$, found 334.0051 . cis-1-[4-(Hydroxymethyl)-2-cyclopenten-1-yl]-5-[ $\left.{ }^{124} \mathrm{I}\right]$ iodocytosine (3). Approximately $4.0 \mathrm{mg}$ of the tributylstannylated compound 13 was dissolved in $5.0 \mathrm{~mL}$ of $\mathrm{MeOH}$. The amount of radioiodide $\left(0.3 \mathrm{mCi}(11.1 \mathrm{MBq}) \mathrm{Na}^{124} \mathrm{I}\right)$ in 0.01 $N$ aqueous $\mathrm{NaOH}$ was added to the precursor 13 solution $(100 \mu \mathrm{L})$. The reaction mixture was acidified to a $\mathrm{pH}$ of 4.0 with $1.0 \mathrm{~N}$ aqueous $\mathrm{HCl}$, and $30 \% \mathrm{H}_{2} \mathrm{O}_{2}(50 \mu \mathrm{L})$ was added. After stirring for $10 \mathrm{~min}$ at ambient temperature, the reaction mixture was quenched with saturated $\mathrm{NaHSO}_{3} .1 .0 \mathrm{~N}$ aqueous $\mathrm{K}_{2} \mathrm{CO}_{3}(100 \mu \mathrm{L})$ was added. After stirring for $1 \mathrm{~h}$ at ambient temperature, the reaction mixture was neutralized with $1.0 \mathrm{~N}$ aqueous $\mathrm{HCl}$ to $\mathrm{pH}$ 7. Purification of the radioiodinated product 3 was performed by HPLC separation on a $\mu$ Bondapak C18 column $(7.8 \mathrm{~mm} \times 300 \mathrm{~mm})$. The product was eluted at a flow rate of $2.0 \mathrm{~mL} / \mathrm{min}$ with $0.1 \%$ trifluoroacetic acid in water/ethanol $(9: 1, \mathrm{v} / \mathrm{v})$. The retention time of the product was $19.65 \mathrm{~min}$. The radiochemical purity of the product was determined by the HPLC system used for purification and radio-thin layer chromatography (radio-TLC). Radio-TLC was performed on a silica-gel plate (Merck 60 F254 aluminum backed silica-gel plates), which was developed with acetonitrile/water $(19: 1, \mathrm{v} / \mathrm{v})$ solvent $\left(R_{f}=0.23\right.$ for the product). The total elapsed time was about 110 minutes, including radioiodination and HPLC purification. The overall radiochemical yield and purity were more than $75 \%(8.33$ $\mathrm{MBq}$ ) and $95 \%$, respectively.

cis-1-[4-(Methoxycarbonyloxymethyl)-2-cyclopenten-1yl]-5-(2-trimethylsilylvinyl) cytosine (15). $(E)-\mathrm{Bu}_{3} \mathrm{SnCH}=$ $\mathrm{CHSiMe}_{3}(2.0 \mathrm{~g}, 5.11 \mathrm{mmol})$ and $\mathrm{Pd}_{2}(\mathrm{dba})_{3}(0.234 \mathrm{~g}, 0.256$ $\mathrm{mmol})$ were added to a solution of compound $12(1.0 \mathrm{~g}, 2.56$ $\mathrm{mmol})$ in anhydrous DMF $(30 \mathrm{~mL})$ at ambient temperature. The reaction mixture was stirred at $60^{\circ} \mathrm{C}$ for $12 \mathrm{~h}$. After removal of the solvent by rotary-evaporation, the residue was diluted with methanol $(10 \mathrm{~mL})$. Silica-gel $(\sim 2.0 \mathrm{~g})$ was added to the solution, and the resulting suspension was dried under reduced pressure. A yellow solid $\mathbf{1 5}\left(R_{f}=0.23 ; 0.56 \mathrm{~g}\right.$, $60 \%$ ) was obtained from preloaded silica-gel column chromatography $\left(\mathrm{CH}_{2} \mathrm{Cl}_{2}: \mathrm{MeOH}=20: 1, \mathrm{v} / \mathrm{v}\right)$. $\mathrm{mp} 123{ }^{\circ} \mathrm{C}$; IR (thin film): $3428,2956,1750,1646,1474,1444,1273,866,841$, $791 \mathrm{~cm}^{-1} ;{ }^{1} \mathrm{H}$ NMR $\left(\mathrm{CDCl}_{3}\right) \delta 7.38(\mathrm{~s}, 1 \mathrm{H}), 6.48(\mathrm{~d}, J=19.2$ $\mathrm{Hz}, 1 \mathrm{H}), 6.13(\mathrm{~d}, J=19.2 \mathrm{~Hz}, 1 \mathrm{H}), 6.11(\mathrm{~m}, 1 \mathrm{H}), 5.84(\mathrm{~m}$, $1 \mathrm{H}), 5.78(\mathrm{~m}, 1 \mathrm{H}), 4.29-4.10(\mathrm{~m}, 2 \mathrm{H}), 3.77(\mathrm{~s}, 3 \mathrm{H}), 3.12(\mathrm{~m}$, $1 \mathrm{H}), 2.85(\mathrm{~m}, 1 \mathrm{H}), 1.41(\mathrm{~m}, 1 \mathrm{H}), 0.14(\mathrm{~m}, 9 \mathrm{H}) ;{ }^{13} \mathrm{C} \mathrm{NMR}$ $\left(\mathrm{CDCl}_{3}\right) \delta 163.45,155.81,155.80,139.78,137.45,134.33$, 131.91, 131.43, 107.24, 69.73. 61.85, 54.90, 44.23, 34.41, -1.26 ; HRMS: calculated for $\mathrm{C}_{17} \mathrm{H}_{25} \mathrm{~N}_{3} \mathrm{O}_{4} \mathrm{Si}$ [ $\left.\mathrm{M}^{+}, \mathrm{FAB}\right]$ 364.1693 , found 364.1695 .

cis-1-[4-(Hydroxymethyl)-2-cyclopenten-1-yl]-5-(2-trimethylsilylvinyl)cytosine (16). Compound $15(0.16 \mathrm{~g}, 0.44$ $\mathrm{mmol}$ ) was added to $0.5 \mathrm{~N}$ aqueous potassium carbonate (1.0 $\mathrm{mL}$ ) and stirred at room temperature for $12 \mathrm{~h}$. The reaction mixture was neutralized to $\mathrm{pH} 7-8$ with $1.0 \mathrm{~N} \mathrm{HCl}$. After removal of the solvent by rotary-evaporation, the residue was diluted with methanol $(10 \mathrm{~mL})$. Silica-gel $(\sim 2.0 \mathrm{~g})$ was added to the solution, and the resulting suspension was dried under reduced pressure. A yellow solid $\mathbf{1 6}\left(R_{f}=0.25 ; 0.125\right.$ g, 93\%) was obtained from preloaded silica-gel column chromatography $\left(\mathrm{CHCl}_{3}: \mathrm{MeOH}=15: 1\right.$ to $\left.10: 1, \mathrm{v} / \mathrm{v}\right)$. $\mathrm{mp}$ $166^{\circ} \mathrm{C}$; IR (thin film): $3341,3202,2953,2895,1644,1592$, $1507,1475,1248,866,840 \mathrm{~cm}^{-1} ;{ }^{1} \mathrm{H}$ NMR $\left(\mathrm{CDCl}_{3}\right) \delta 7.55$ (s, $1 \mathrm{H}), 6.44(\mathrm{~d}, J=19.2 \mathrm{~Hz}, 1 \mathrm{H}), 6.14(\mathrm{~m}, 1 \mathrm{H}), 6.08(\mathrm{~d}, J=$ $19.2 \mathrm{~Hz}, 1 \mathrm{H}), 5.74(\mathrm{~m}, 1 \mathrm{H}), 5.73(\mathrm{~m}, 1 \mathrm{H}), 4.77(\mathrm{~m}, 1 \mathrm{H})$, 3.77-3.66 (m, 2H), $2.79(\mathrm{~m}, 1 \mathrm{H}), 2.75(\mathrm{~m}, 1 \mathrm{H}), 1.50(\mathrm{~m}, 1 \mathrm{H})$, $0.13(\mathrm{~s}, 9 \mathrm{H}) ;{ }^{13} \mathrm{C} \mathrm{NMR}\left(\mathrm{CDCl}_{3}\right) \delta 163.17,155.88,140.59$, 138.67, 134.21, 131.95, 130.98, 106.89, 65.04, 62.48, 47.38, 34.07, -1.27; HRMS: calculated for $\mathrm{C}_{15} \mathrm{H}_{23} \mathrm{~N}_{3} \mathrm{O}_{2} \mathrm{Si}\left[\mathrm{M}^{+}\right.$, FAB] 306.1638 , found 306.1642 .

cis-1-[4-(Hydroxymethyl)-2-cyclopenten-1-yl]-5-(2-iodovinyl)cytosine (17). $\mathrm{ICl}(0.053 \mathrm{~g}, 0.33 \mathrm{mmol})$ was added into solution of compound $16(0.10 \mathrm{~g}, 0.33 \mathrm{mmol})$ in acetonitrile $(8.0 \mathrm{~mL})$. The reaction mixture was stirred at ambient temperature for $30 \mathrm{~min}$. After removal of the solvent by rotary-evaporation, a yellow solid $\mathbf{1 7}\left(R_{f}=0.24 ; 0.082 \mathrm{~g}\right.$, $70 \%$ ) was obtained from silica-gel column chromatography $\left(\mathrm{CH}_{2} \mathrm{Cl}_{2}: \mathrm{MeOH}=10: 1, \mathrm{v} / \mathrm{v}\right)$. mp $145{ }^{\circ} \mathrm{C}$; IR (thin film): 3362 , 3255, 3050, 2929, 2873, 1635, 1501, 1488, 1401, 1290, $1223 \mathrm{~cm}^{-1} ;{ }^{1} \mathrm{H}$ NMR (DMSO- $\left.d_{6}\right) \delta 7.68(\mathrm{~s}, 1 \mathrm{H}), 7.19$ (br s, $1 \mathrm{H}), 7.28(\mathrm{~d}, J=14.6 \mathrm{~Hz}, 1 \mathrm{H}), 6.63(\mathrm{~d}, J=14.6 \mathrm{~Hz}$, $1 \mathrm{H}), 6.08(\mathrm{~m}, 1 \mathrm{H}), 5.71(\mathrm{~m}, 1 \mathrm{H}), 5.56(\mathrm{~m}, 1 \mathrm{H}), 4.80(\mathrm{~m}, 1 \mathrm{H})$, 3.54-3.38 (m, 2H), $2.80(\mathrm{~m}, 1 \mathrm{H}), 2.51(\mathrm{~m}, 1 \mathrm{H}), 1.35(\mathrm{~m}, 1 \mathrm{H})$; ${ }^{13} \mathrm{C}$ NMR (DMSO- $\left.d_{6}\right) \delta 162.44,155.23,140.36,139.70$, 136.22, 130.72, 105.48, 77.29. 63.81, 61.76, 47.75, 34.12; HRMS: calculated for $\mathrm{C}_{12} \mathrm{H}_{15} \mathrm{~N}_{3} \mathrm{O}_{2} \mathrm{I}\left[\mathrm{M}^{+}\right.$, FAB] 360.0209, found 360.0205 .

cis-1-[4-(Hydroxymethyl)-2-cyclopenten-1-yl]-5-(2-[ $\left.{ }^{124} \mathrm{I}\right]-$ iodovinyl)cytosine (4). Approximately $4.0 \mathrm{mg}$ of trimethylsilyl compound 16 was dissolved in $5.0 \mathrm{~mL}$ of $\mathrm{MeOH}$. The amount of radioiodide $\left(0.3 \mathrm{mCi}(11.1 \mathrm{MBq}) \mathrm{Na}^{124} \mathrm{I}\right)$ in 0.01 $N$ aqueous $\mathrm{NaOH}$ was added to the precursor 16 solution $(100 \mu \mathrm{L})$. The reaction mixture was acidified to a $\mathrm{pH}$ of 4.0 with $1.0 \mathrm{~N}$ aqueous $\mathrm{HCl}$, and $30 \% \mathrm{H}_{2} \mathrm{O}_{2}(50 \mu \mathrm{L})$ was added. After stirring for $10 \mathrm{~min}$ at ambient temperature, the reaction mixture was quenched with saturated $\mathrm{NaHSO}_{3}$. Purification of the radioiodinated product 4 was performed by HPLC separation on a $\mu$ Bondapak $\mathrm{C} 18$ column $(7.8 \mathrm{~mm} \times 300$ $\mathrm{mm})$. The product was eluted at a flow rate of $2.0 \mathrm{~mL} / \mathrm{min}$ with $0.1 \%$ trifluoroacetic acid in water/acetonitrile $(4: 1, \mathrm{v} / \mathrm{v})$. The retention time of the product was $17.0 \mathrm{~min}$. The radiochemical purity of the product was determined by the HPLC system used for purification and radio-thin layer chromatography (radio-TLC). Radio-TLC was performed on a silicagel plate (Merck 60 F254 aluminum backed silica-gel plates), which was developed with acetonitrile/water $(19: 1, \mathrm{v} / \mathrm{v})$ solvent $\left(R_{f}=0.53\right.$ for the product). The total elapsed time was about 60 minutes, including radioiodination and HPLC purification. The overall radiochemical yield and purity were more than $80 \%(8.88 \mathrm{MBq})$ and $95 \%$, respectively.

Acknowledgments. This research was supported by the Basic Science Research Program (2009-0070920) and the Nuclear R\&D program (2010-0005313) through the National Research Foundation of Korea (NRF) funded by the Ministry of Education, Science and Technology. H.A. greatly appreciates 
the Korean Ministry of Education through the second stage of the BK21 project for the Hanyang University graduate program and Seoul Metropolitan Government for Seoul Science Fellowship for financial support.

\section{References}

1. (a) Kwon, H. C.; Kim, J. H.; Kim, K. C.; Lee, K. H.; Lee, J. H.; Lee, B. H.; Lee, K. H.; Jang, J. J.; Lee, C. T.; Lee, H.; Kim, C. M. Mol. Cells 2001, 11, 170. (b) Mullen, C. A. Pharm. Ther. 1994, 63, 199. (c) Choi, T. H.; Ahn, S. H.; Kwon, H. C.; Choi, C. W.; Awh, O. D.; Lim, S. M. Appl. Radiat. Isot. 2004, 60, 15. (c) Haberkorn, U.; Khazaie, K.; Morr, I.; Altmann, A.; Muller, M.; Kaick, G. V. Nucl. Med. Biol. 1998, 25, 367.

2. (a) Tjuvajev, J. G.; Doubrovin, M.; Akhurst, T.; Cai, S.; Alauddin, J. M. M.; Finn, R.; Bornmann, W.; Thaler, H.; Conti, P. S.; Blasberg, R. G. J. Nucl. Med. 2002, 43, 1072. (b) Manger, T. J.; Klecker, R. W.; Anderson, L.; Shields, A. F. Nucl. Med. Biol. 2003, 30, 215. (c) Morin, K. W.; Atrazheva, E. D.; Knaus, E. E.; Weibe, L. I. J. Med. Chem. 1997, 40, 2184. (d) Alauddin, M. M.; Shahinian,A.; Park, R.; Tohme, M.; Fissekis, J. D.; Conti, P. S. J. Nucl. Med. 2004, 45, 2063.

3. (a) Morin, K. W.; Duan, W.; Zhou, A.; Xu, L.; Moharram, S.; Knaus, E. E.; McEwan, A. J. B.; Wiebe, L. I. Nucl. Med. Biol. 2004, 31, 623. (b) Toyohara, J.; Hayashi, A.; Sato, M.; Tanaka, H.; Haraguchi, K.; Yoshimura, Y.; Yonekura, Y.; Fujibayashi, Y. J. Nucl. Med. 2002, 43, 1218. (c) Toyohara, J.; Hayashi, A.; Sato, M.; Gogami, A.; Tanaka, H.; Haraguchi, K.; Yoshimura, Y.; Kumamoto, H.; Yonekura, Y.; Fujibayashi, Y. Nucl. Med. Bio. 2003, 30, 687.

4. (a) Borthwick, A. D.; Biggadike, K. Tetrahedron 1992, 48, 571. (b) Herdewijn, P.; Clercq, E. D.; Balzarini, J.; Vanderhaeghe, H. J. Med. Chem. 1985, 28, 550. (c) Shi, J.; McAtee, J. J.; Wirtz, S. S.; Tharnish, P.; Juodawlkis, A.; Liotta, D. C.; Schinazi, R. F. J. Med.
Chem. 1999, 42, 859. (d) Wang, J.; Jin, Y.; Rapp, K. L.; Benneth, M.; Schinazi, R. F.; Chu, C. K. J. Med. Chem. 2005, 48, 3736. (e) Agrofolio, L.; Suhas, E.; Farese, A.; Condom, R.; Challand, S. R.; Earl, R. A.; Guedj, R. Tetrahedron 1994, 50, 10611.

5. (a) An, G.; Rhee, H. Nucleosides Nucleotides Nucleic Acids 2000 , 19, 1111. (b) An, G.; Rhee, H. Nucleosides Nucleotides Nucleic Acids 2002, 21, 65. (c) An, G.; Rhee, H. Nucleosides Nucleotides Nucleic Acids 2003, 22, 437.

6. Ahn, H.; Choi, T. H.; Castro, K. D. A.; Lee, K. C.; Kim, B.; Moon, B. S.; Hong, S. H.; Lee, J. C.; Chun, K. S.; Cheon, G. J.; Lim, S. M.; An, G.; Rhee, H. J. Med. Chem. 2007, 50, 6032.

7. Kim, E.; Choi, T. H.; Ahn, S. H.; Kim, B.; Park, H.; Cheon, G. J.; Rhee, H.; An, G. Nucl. Med. Mol. Imaging 2009, 43, 478.

8. Kim, J.; Castro, K. D. A.; Lim, M.; Rhee, H. Tetrahedron 2010 , 66, 3995.

9. (a) Schneekloth, J. S.; Mathieu, P.; Crews, C. M. Eur. J. Org. Chem. 2007, 40. (b) Negishi, E. Handbook of Organopalladium Chemistry for Organic Synthesis; John Wiley \& Sons, Inc.: Hoboken, N. J., USA, 2002, 1, 693-719.

10. (a) Sabbatini, P.; Wellendorph, P.; Hoeg, S.; Pedersen, M. H. F.; Brauner-Osborne, H.; Martiny, L.; Froelund, B.; Clausen, R. P. J. Med. Chem. 2010, 53, 6506. (b) Wang, B.; Qin, L.; Neumann, K. D.; Uppaluri, S.; Cerny, R. D.; Magno, S. G. D. Org. Lett. 2010, 12, 3352. (c) Watanabe, H.; Ono, M.; Haratake, M.; Kobashi, N.; Saji, H.; Nakayama, M. Bioorg. Med. Chem. 2010, 18, 4740.

11. (a) Durka, K.; Gorka, J.; Kurach, P.; Lulinski, S.; Serwatowski, J. J. Organomet. Chem. 2010, 695, 2635. (b) Widhalm, M.; Abraham, M.; Arion, V. B.; Saarsalu, S.; Maeorg, U. Tetrahedron: Asymm. 2010, 21, 1971. (c) Denmark S. E.; Muhuhi, J. M. J. Am. Chem. Soc. 2010, 132, 11768.

12. (a) Bukovec, C.; Wesquet, A. O.; Kazmaier, U. Eur. J. Org. Chem. 2011, 1047. (b) Perez-Temprano, M. H.; Gallego, A. M.; Casares, J. A.; Espinet, P. Organometallics 2011, 30, 611. (c) Yabe, Y.; Maegawa, T.; Monguchi, Y.; Sajiki, H. Tetrahedron 2010, 66, 8654. 


\section{Supporting Information}

\section{Synthesis of Radioiodinated Carbocyclic Cytosine Analogues}

Hyunseok Ahn, ${ }^{\dagger}$ Gwangil An, ${ }^{\star}$ and Hakjune Rhee ${ }^{\dagger, \S, *}$

${ }^{\dagger}$ Department of Bionanotechnology, Hanyang University, Kyunggi-do 426-791 Korea. *E-mail: hrhee@hanyang.ac.kr Laboratory of Radiopharmaceuticals and Laboratory of Nuclear Medicine, Seoul 139-706, Korea ${ }^{\S}$ Department of Chemistry and Applied Chemistry, Hanyang University, Kyunggi-do 426-791 Korea Received March 29, 2011, Accepted April 21, 2011 
cis-1-[4-(Methoxycarbonyloxymethyl)-2-cyclopenten-1-yl]-5-iodocytosine (12)

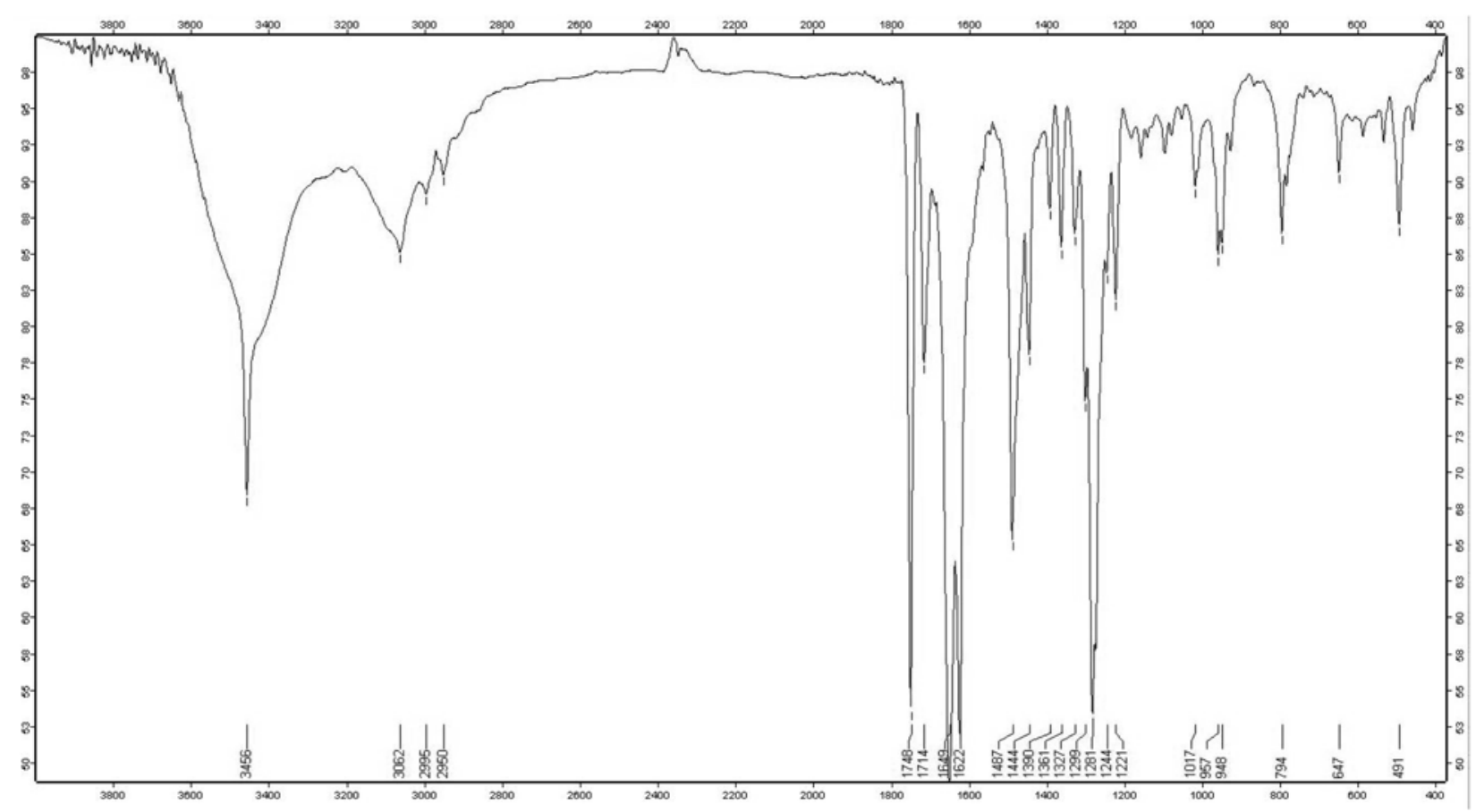

ahs-269-d4ic-coup 1 ing

Pulse Sequence: s2pul

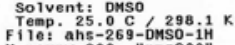

Relax. delay 2.000 se

Pulse 85.5 degrees

Actith $4001,6 \mathrm{H}$

OBSERVEt H1 $300.0746498 \mathrm{MHZ}$

FT size $16384 \mathrm{~min}, 5 \mathrm{sec}$

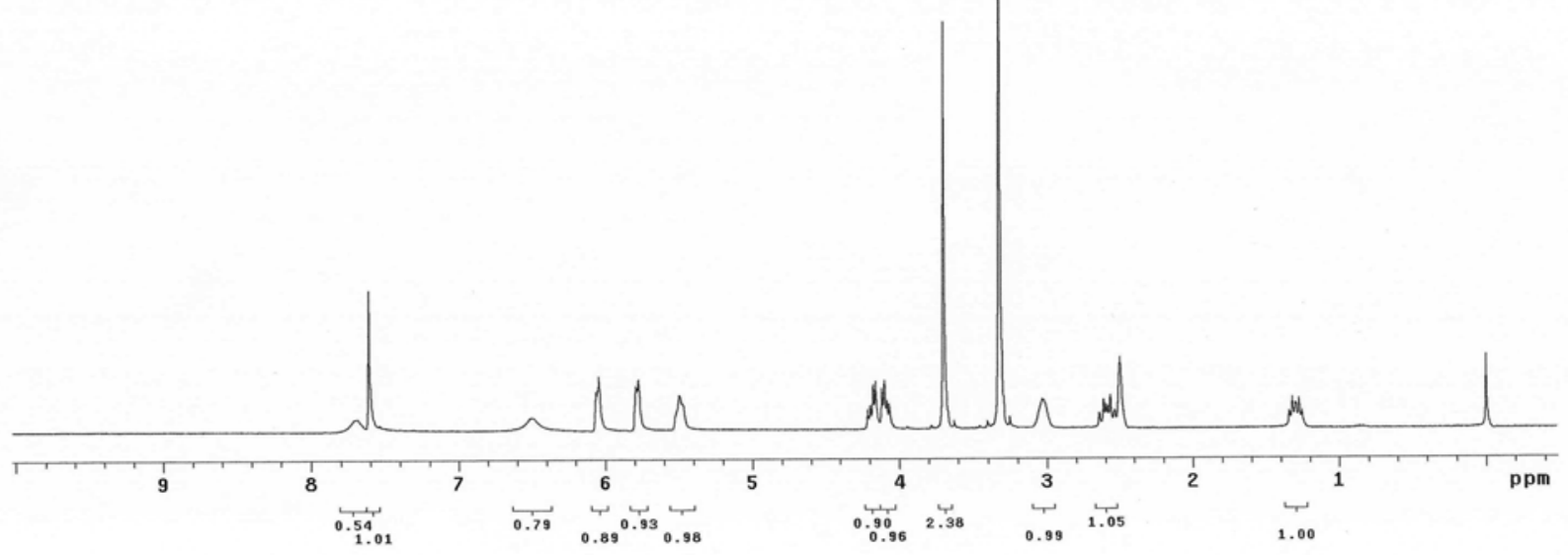



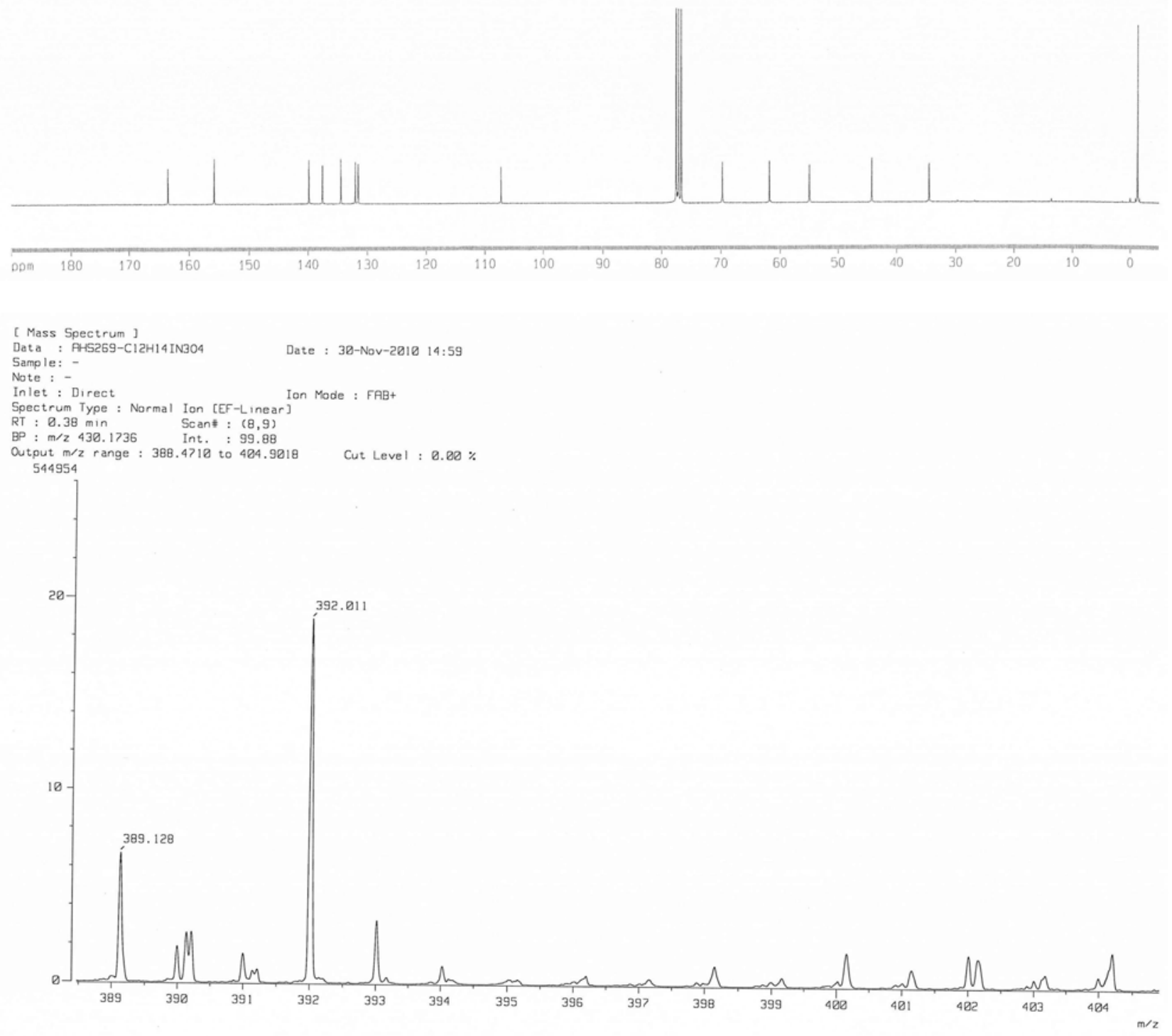
cis-1-[4-(Methoxycarbonyloxymethyl)-2-cyclopenten-1-yl]-5-tributylstannylcytosine (13)

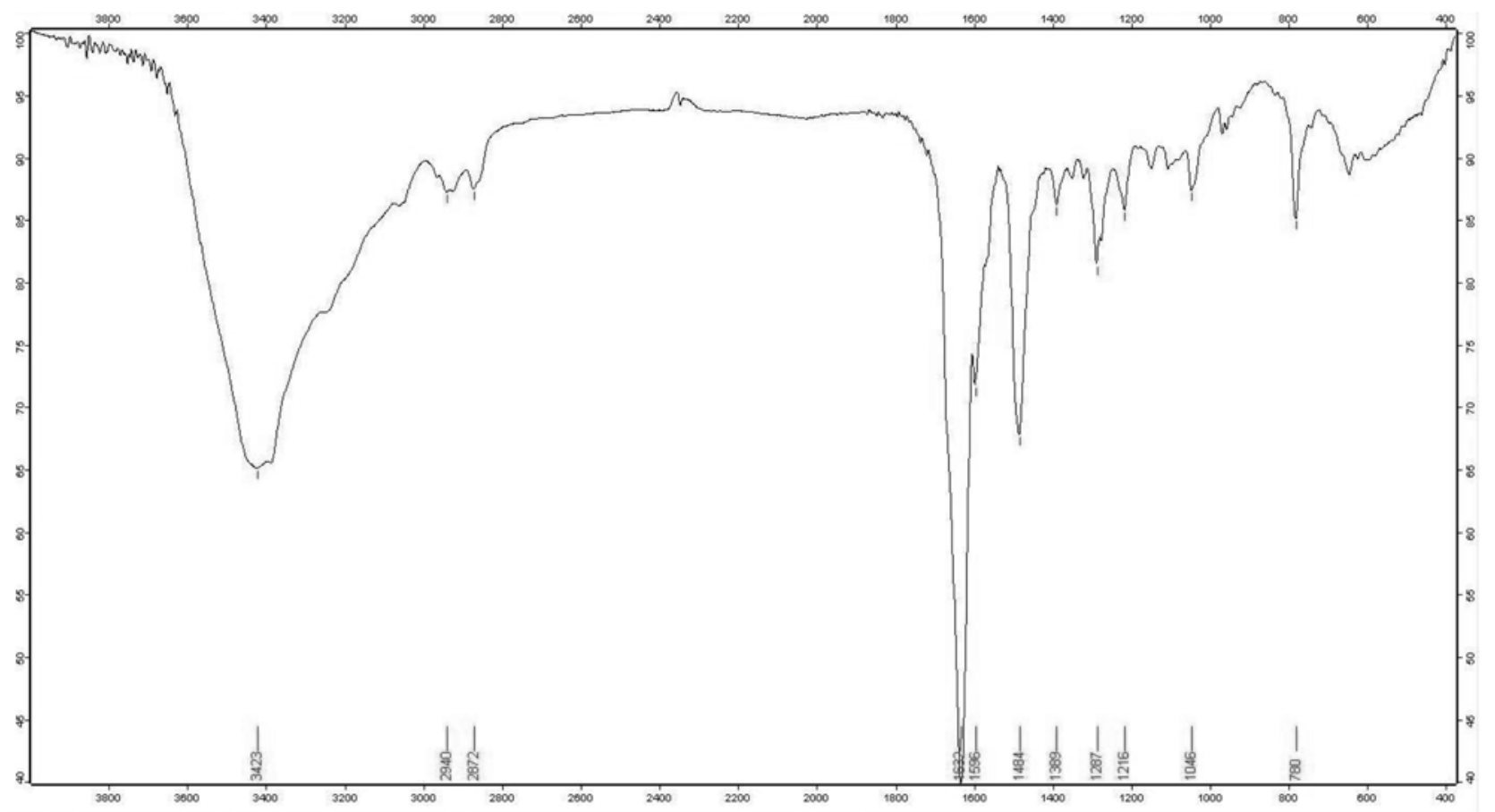

ahs-276-d4IC

Pulse Sequence: s2pui

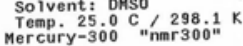

Relax. delay $2.000 \mathrm{sec}$

Puise 85.5 degrees

Acq. ${ }^{\text {time }} 1.999$ sec

16 repetitions
OBSERVE H1, 300.0746498 MH

DATA PROCESSI

Total time $1 \mathrm{~min}, 5 \mathrm{sec}$ 
Std carbon

Samp 1e: ahs -276
File: ${ }_{\text {exp }}$

Pulse Sequence: s2pul

Solvent: dmso $298.1 \mathrm{~K}$

Operator: vnmer 1
vwMrS-500 "hyunmr 600 "

Relax. de lay $1.000 \mathrm{sec}$

Acq. time $1.300 \mathrm{sec}$

Width $30487.8 \mathrm{~Hz}$

OBSERVE C13, 125.7165278 MHZ

Power $44 \mathrm{~dB}$
cont

cont inuous ly on
WALT $12-16$ modulate

DATA PROCESSING $0.5 \mathrm{~Hz}$

Total time $64 \mathrm{hr}, 9 \mathrm{~min}, 2 \mathrm{sec}$ 
cis-1-[4-(Hydroxymethyl)-2-cyclopenten-1-yl]-5-iodocytosine (14)

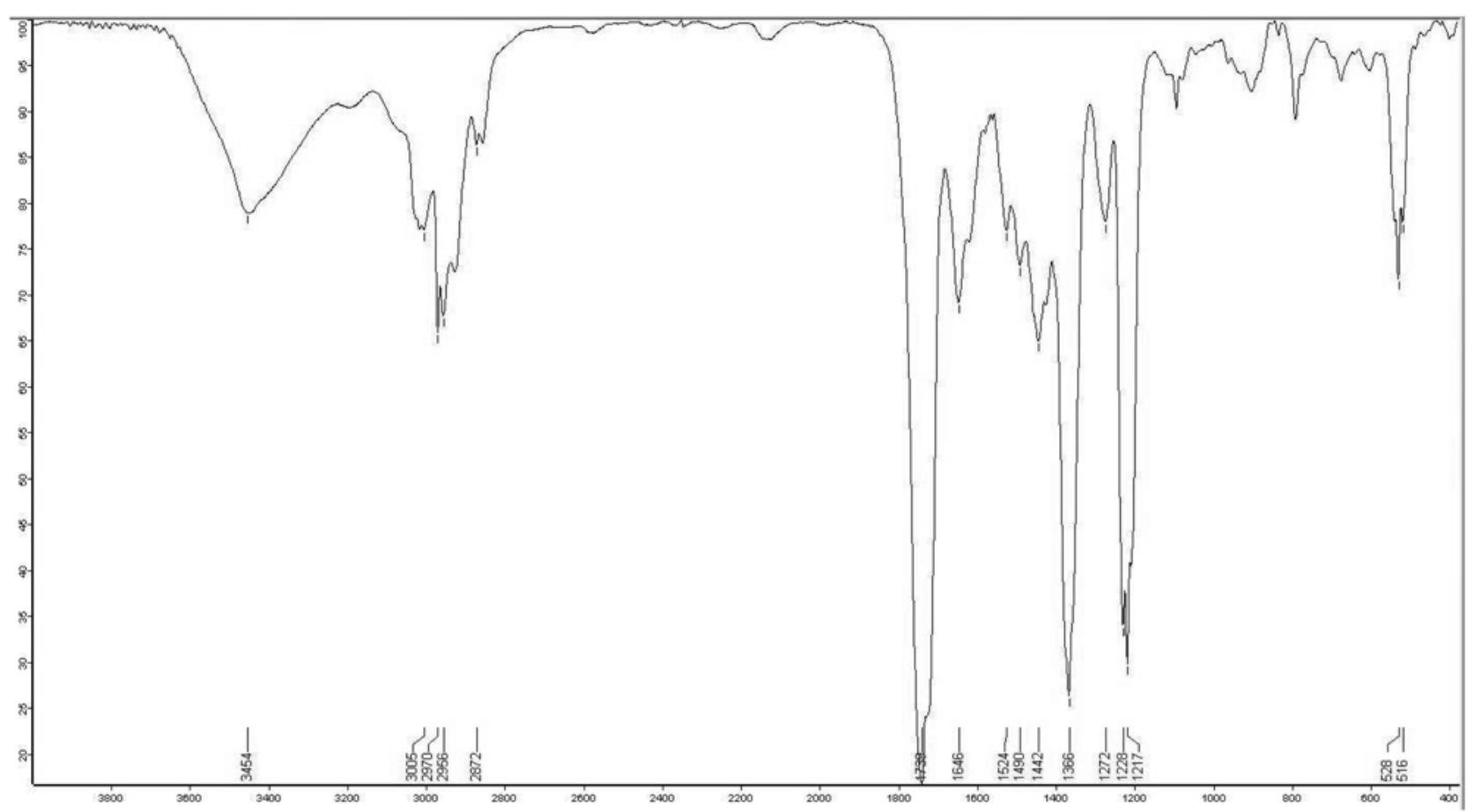

Std proton

Sample: ahs-271-1H
File: /home/vnmr 1/vnmrsys/data/hank/20100205-ahs-271-1H.fid

Pulse Sequence: 52pul

Solvent: cdc13
Ambient temperature

pperator: vnmer 1

File: 20100205 -ahs $-271-1 \mathrm{H}$
VNMRS-500 "hyunmr600"

Relax. de lay $1.000 \mathrm{sec}$

Acq. time $2.049 \mathrm{sec}$

15 the $8012.8 \mathrm{~Hz}$

OBSERVE H1, $499.9635234 \mathrm{MHZ}$

Desol

FT size 65536

Total time $0 \mathrm{~min}, 55 \mathrm{sec}$ 
Std carbon

Sample: 20100203-mixedproduct
File: /home/vnmr1/vnmrsys/data/hank/20100205-ahs-271-13C.fid

Pulse Sequence: s2pul

Solvent: cdc13 13
Ambient temperature

Operator: vnmin 1
File: 20100205 -ahs $-271-13 C$

Re lax. de lay $1.000 \mathrm{sec}$

Acq. time 1.300 se

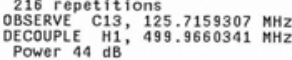

Power 44 dB
cont inous ly on
WAL TZ-16 modulated

Line broadening $0.5 \mathrm{~Hz}$

Total time $6415 \mathrm{hr}, 4 \mathrm{~min}, 8 \mathrm{sec}$

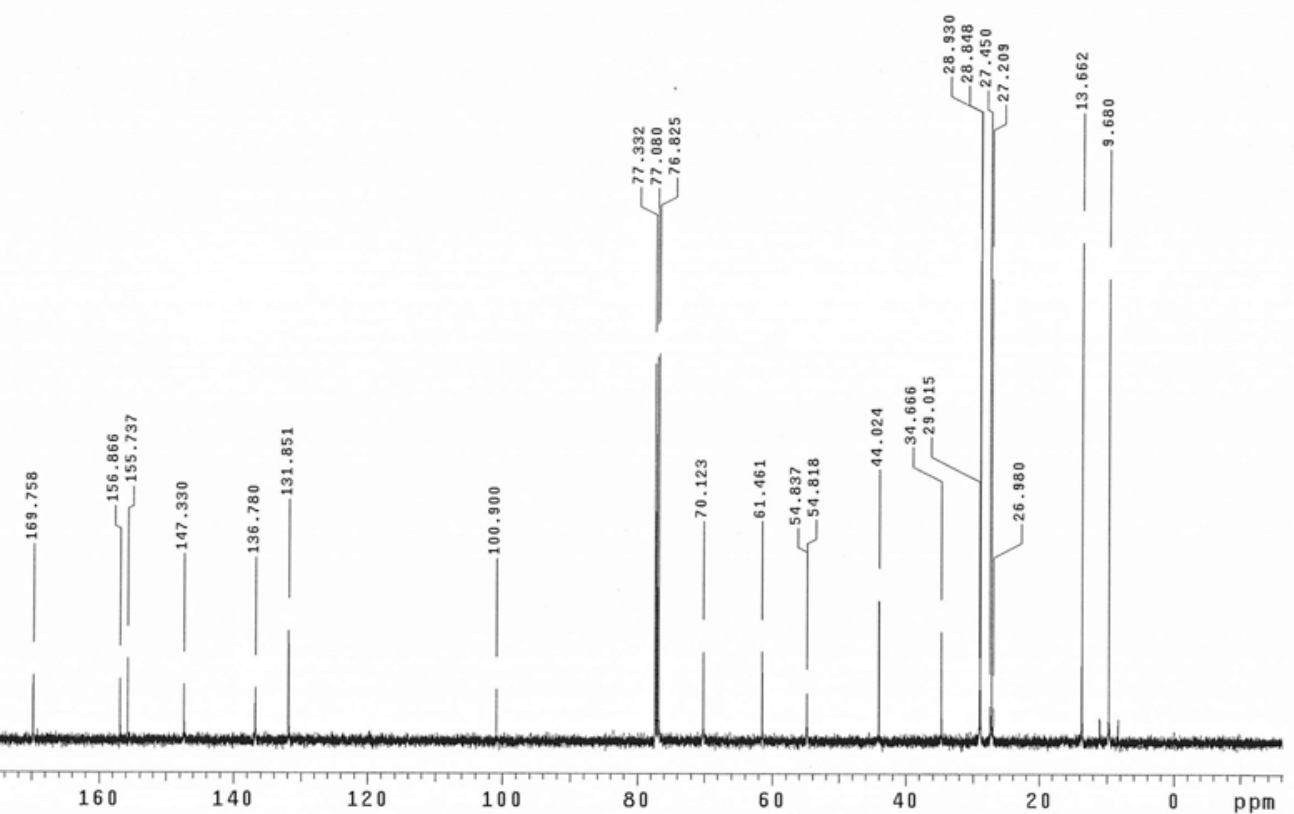

[ Mass Spectrum ]

Data : AHS271-C24H43N304Sn

Sample:

Note : Direct

Spectrum Type : Normal Ion [EF-Linear]
RT : O. 68 min
Scan : $:(14,15)$

RT : 8.68 min : Normal Ion (EF $-(4,14,15)$

Output $\mathrm{m} / \mathrm{z}$ range : 543.6202 to 568.368

Output $m / 2$
1605761

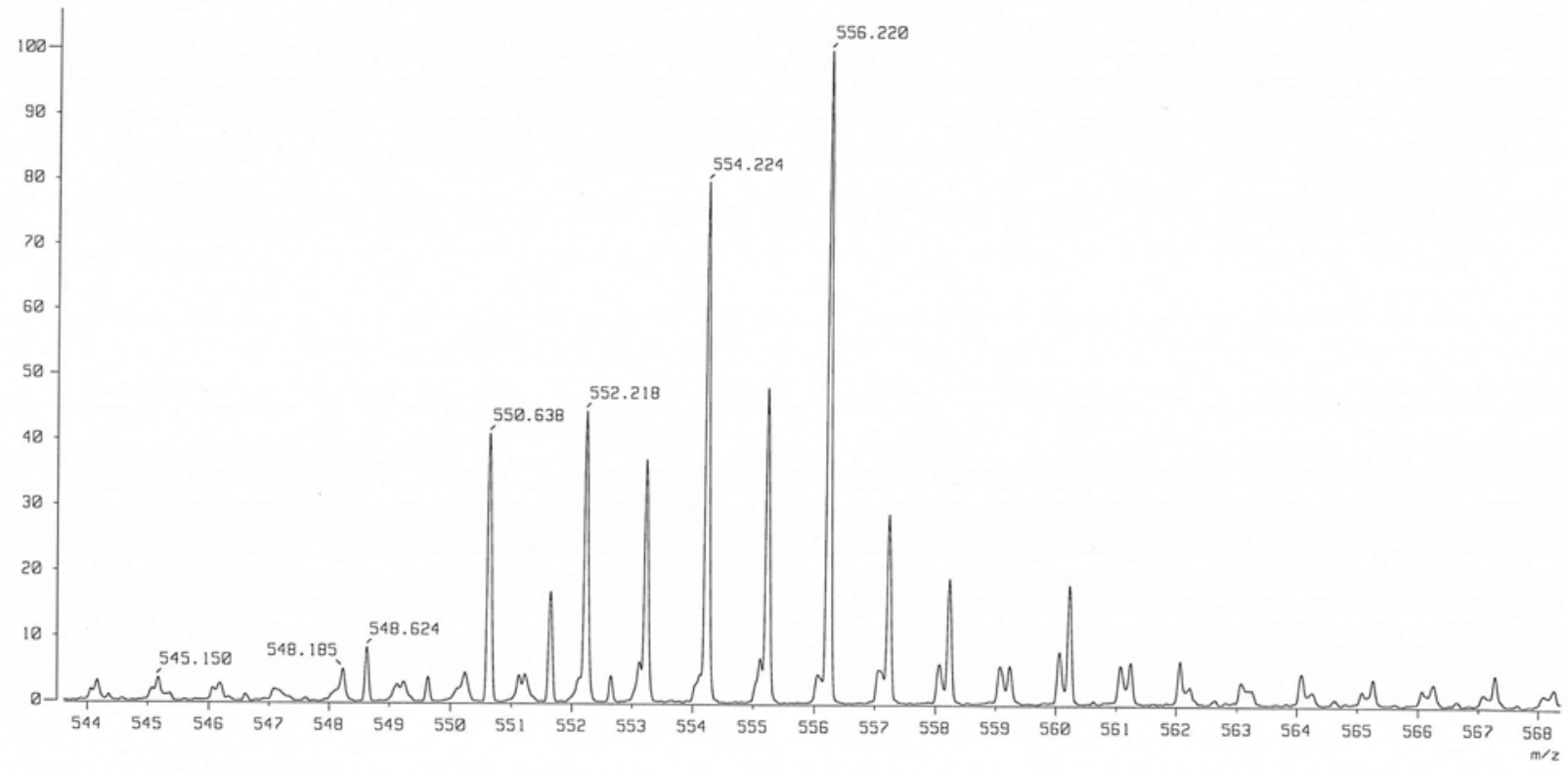


cis-1-[4-(Methoxycarbonyloxymethyl)-2-cyclopenten-1-yl]-5-(2-trimethylsilylvinyl)cytosine (15)
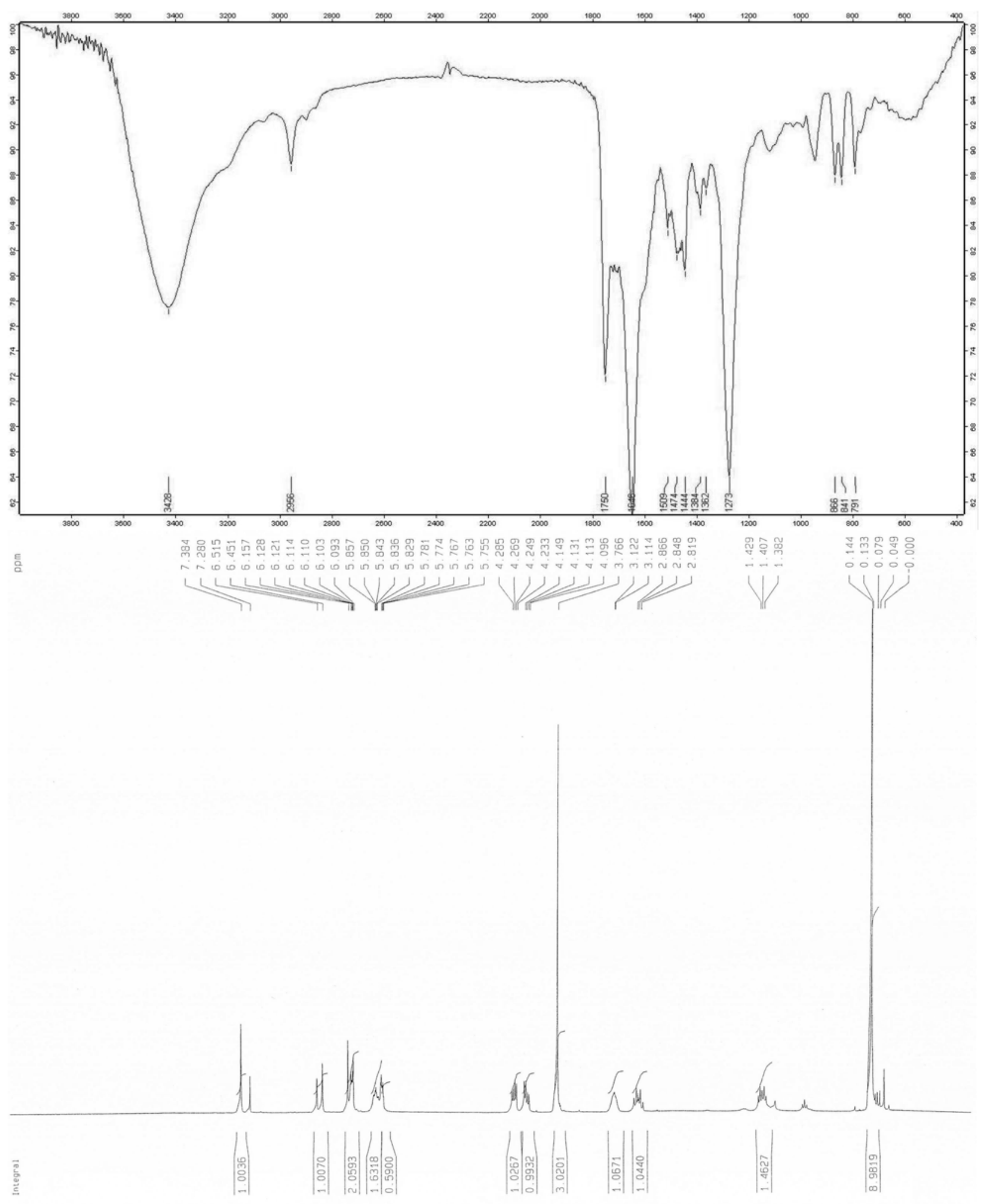


言

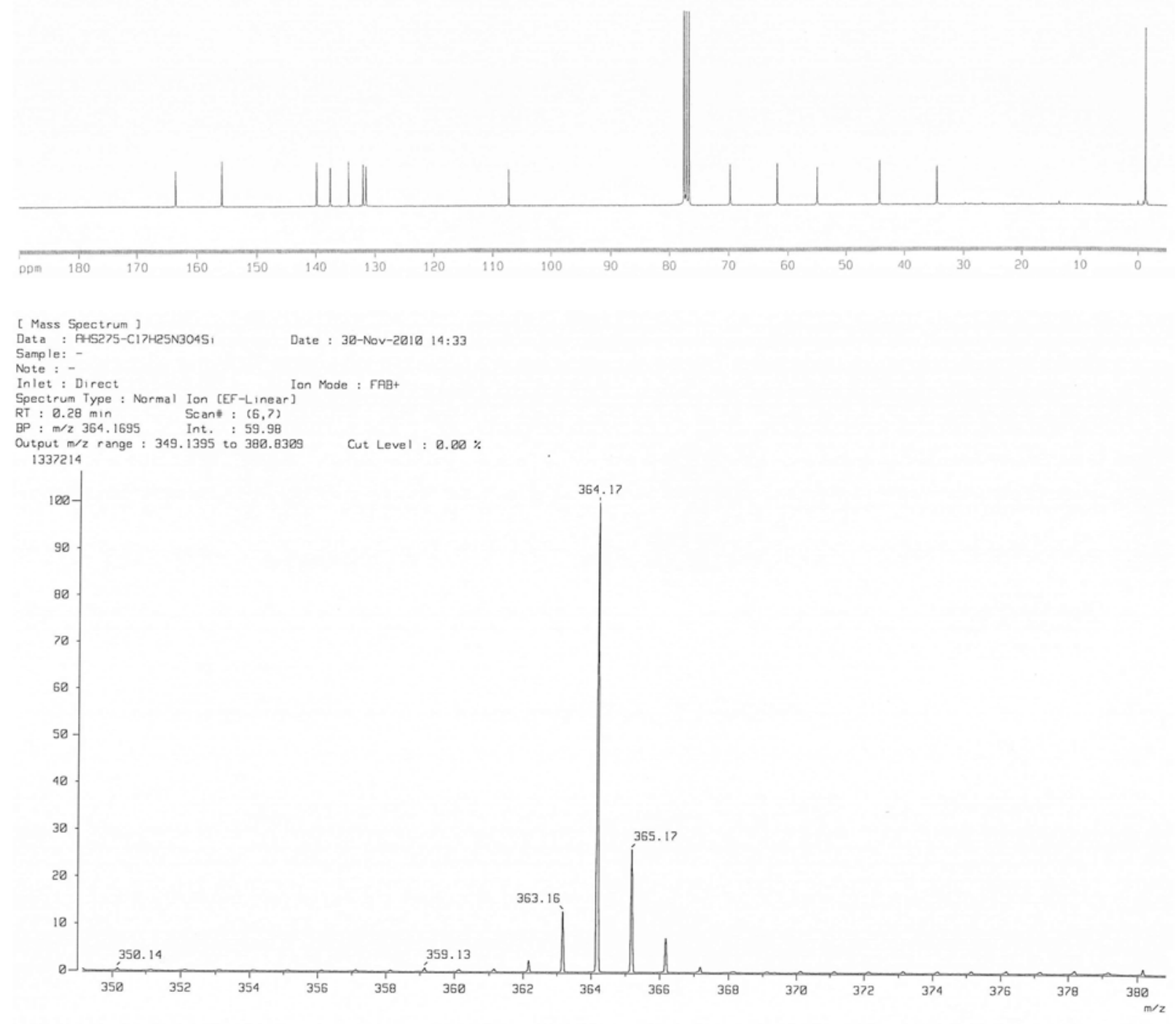


cis-1-[4-(Hydroxymethyl)-2-cyclopenten-1-yl]-5-(2-trimethylsilylvinyl)cytosine (16)
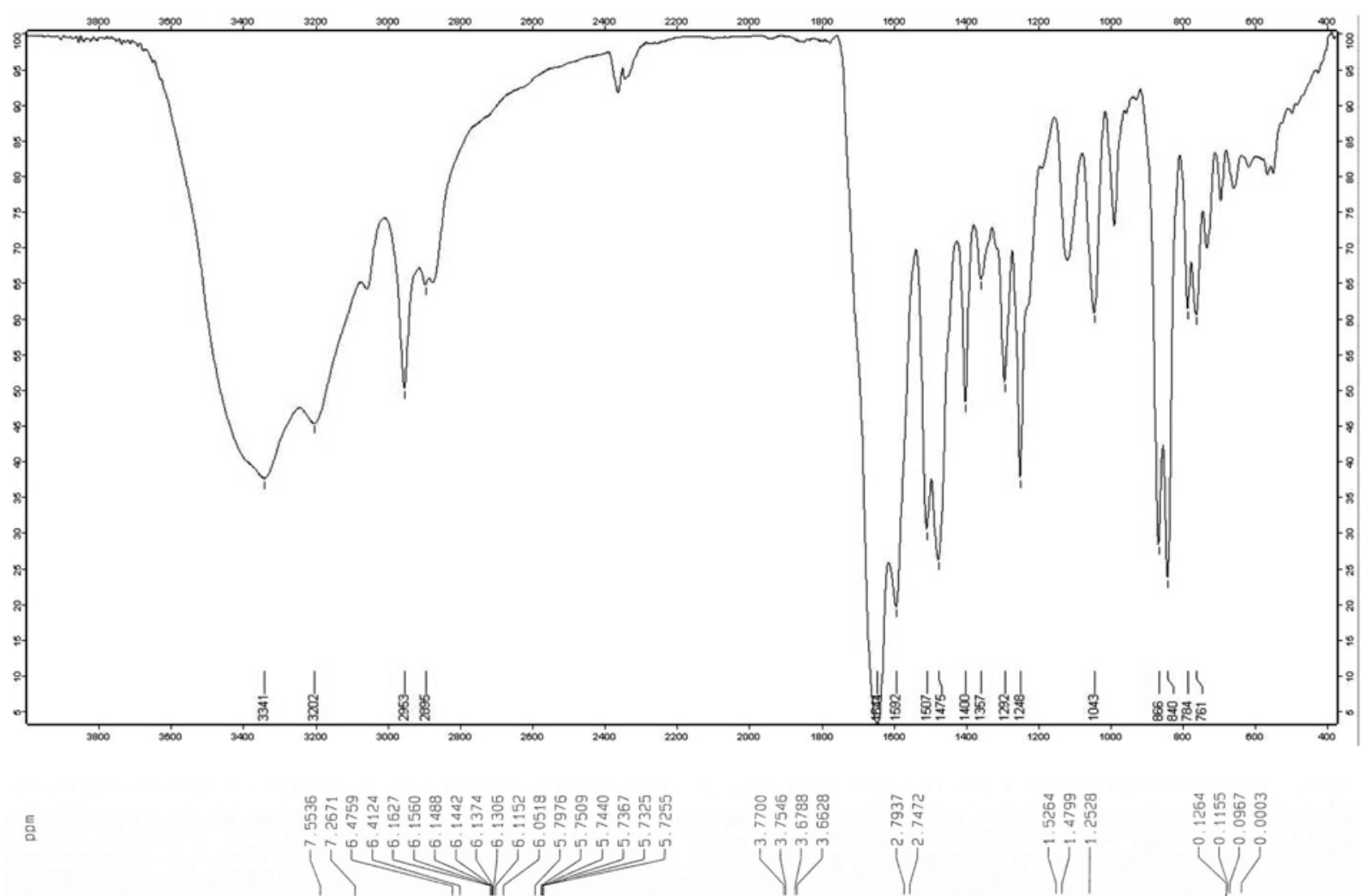

\section{nit}
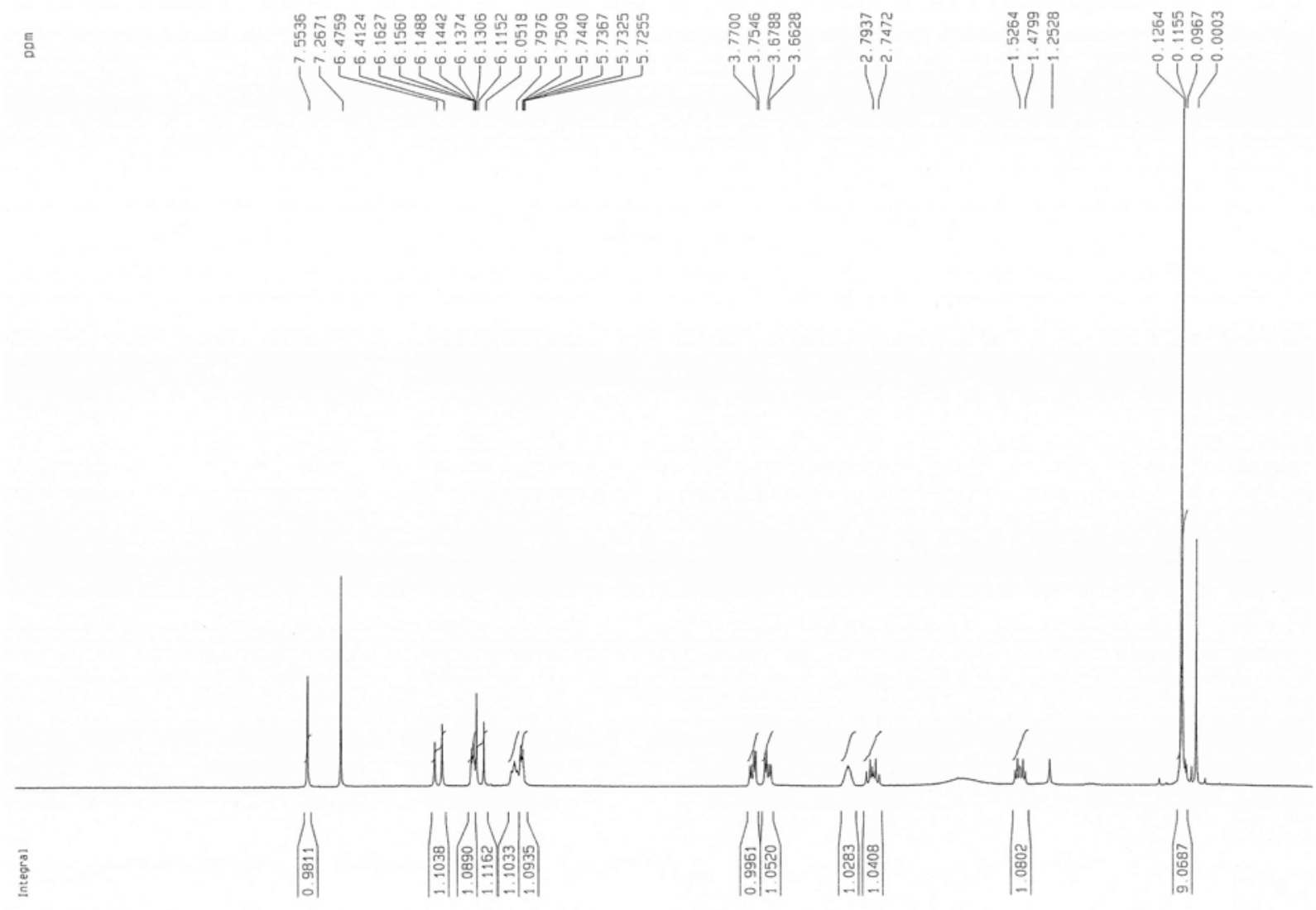


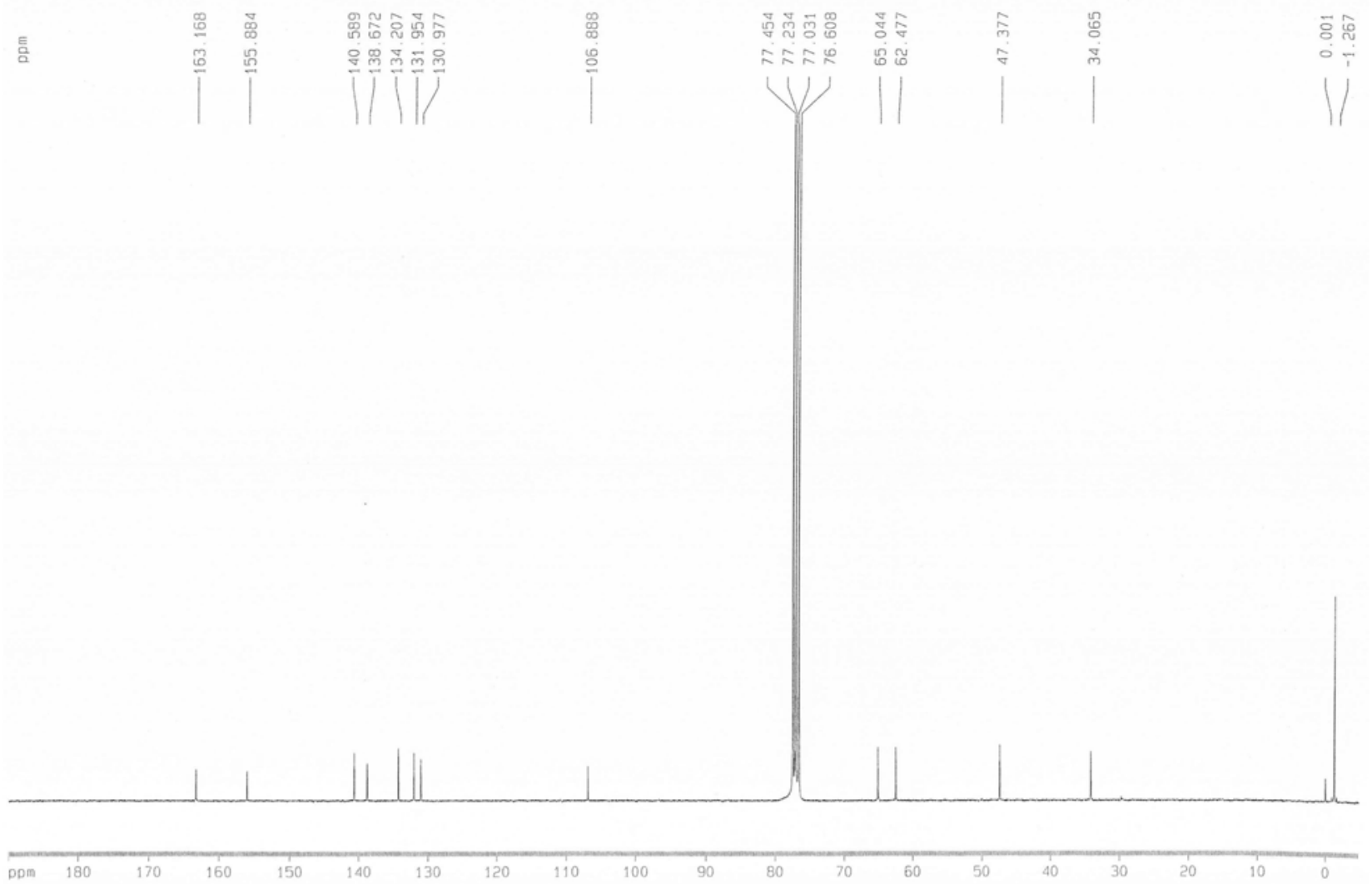

[ Mass Spectrum ]

Data : HHS279-CI5H23N302Si Date : 38-Nov-2810 14:28

Sample:

Inlet : Direct

Ion Mode : $\mathrm{FAB}^{+}$

Spectrum Type : Normal Ion [EF-Linear]

$\begin{array}{ll}\text { RT : } 0.28 \min & \text { Scant : }(6,7) \\ \text { BP : } m / 2386.1642 & \text { Int. }: 94.58\end{array}$

Output $\mathrm{m} / 2$ range : 295.4978 to 318.1386

2868483

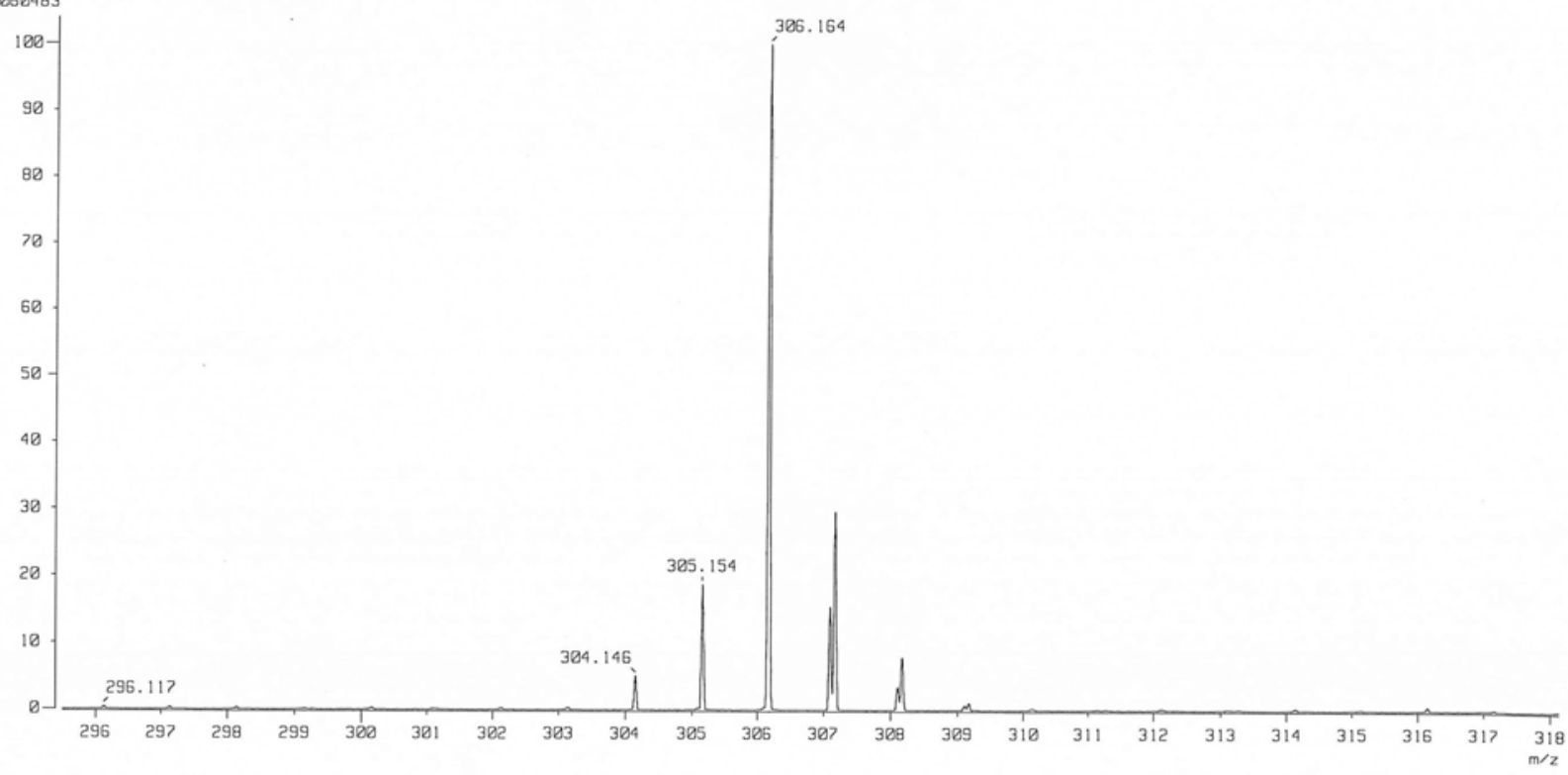


cis-1-[4-(Hydroxymethyl)-2-cyclopenten-1-yl]-5-(2-iodovinyl)cytosine (17)

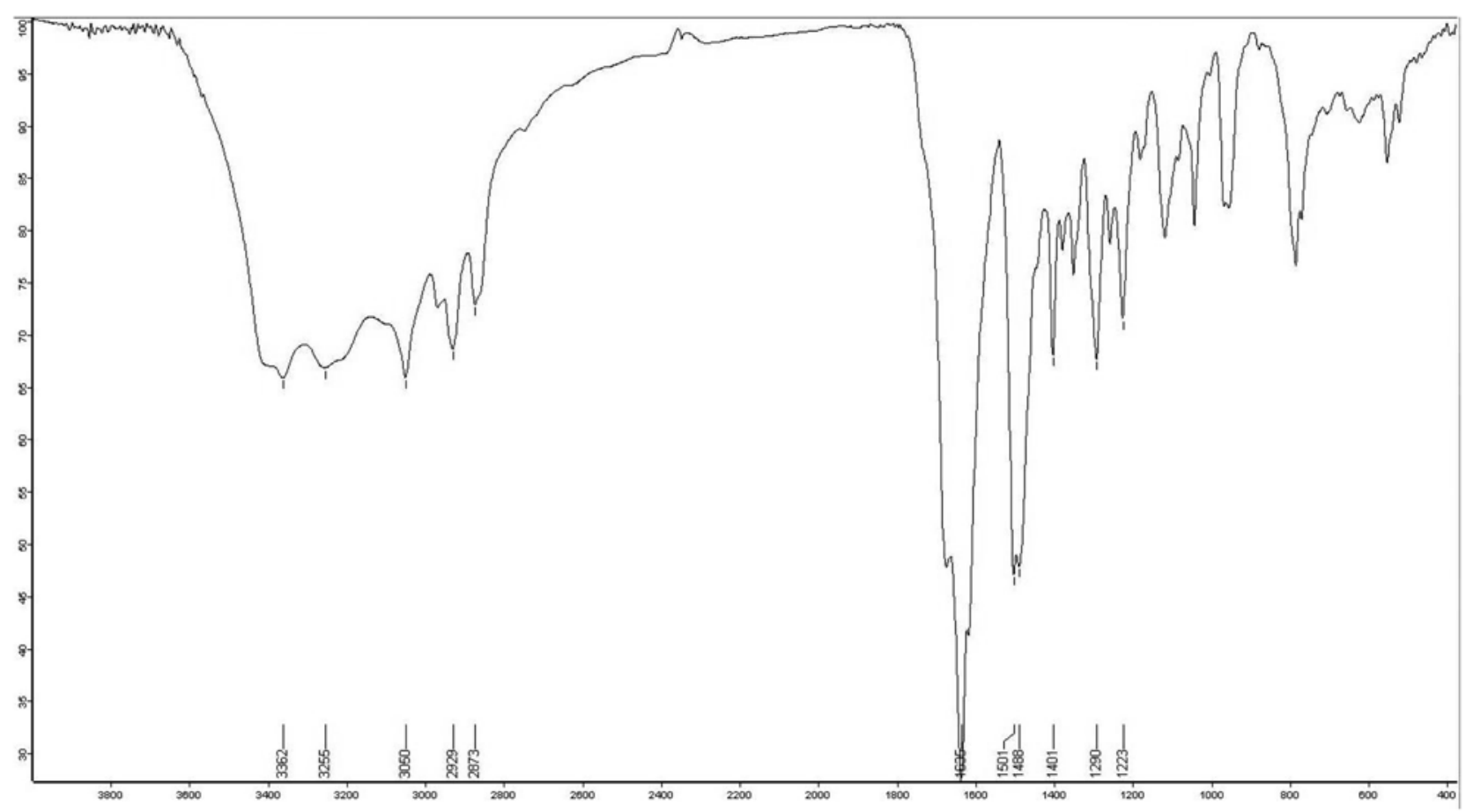

票

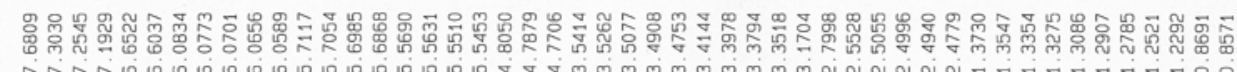
远选造

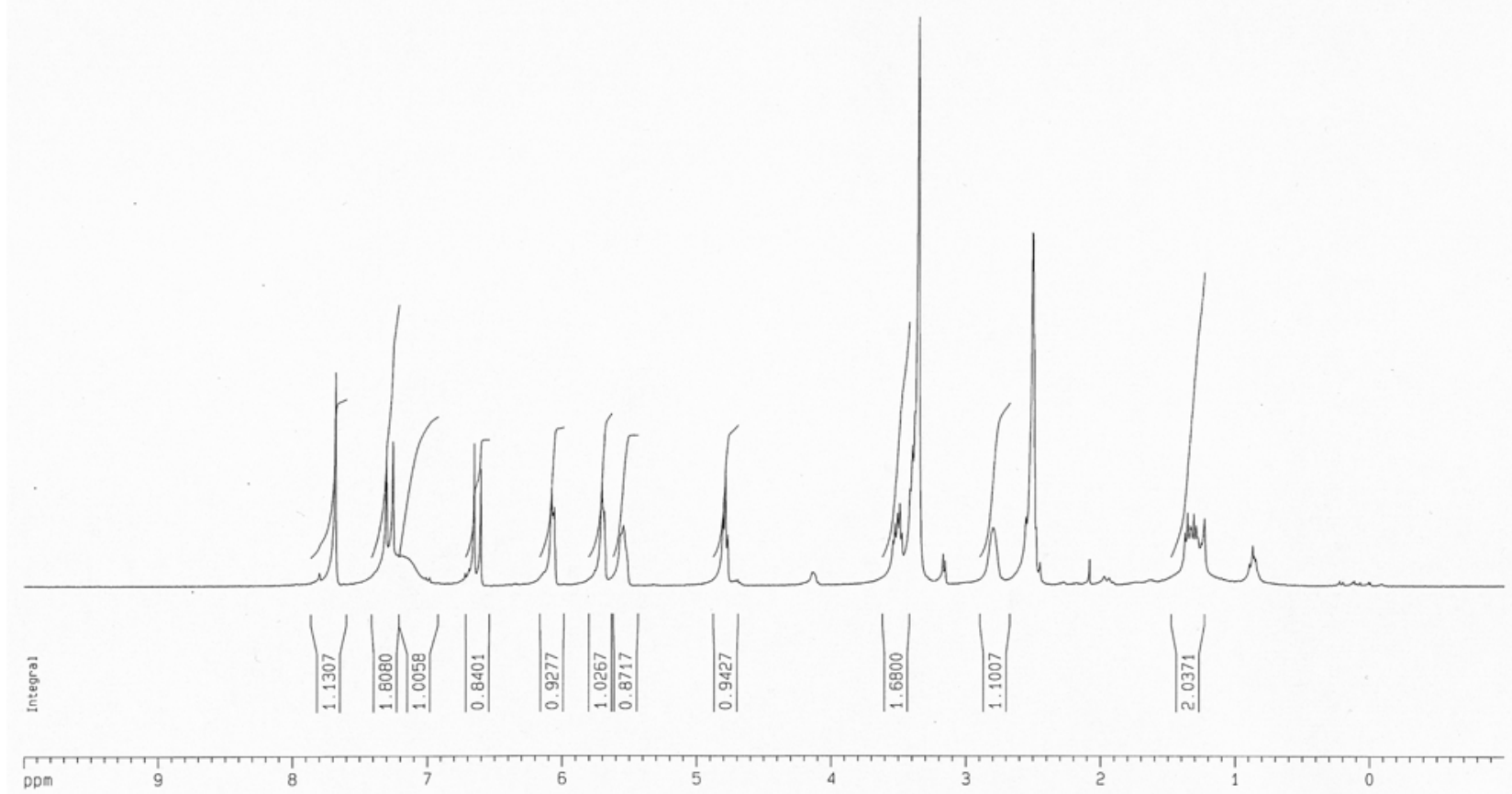




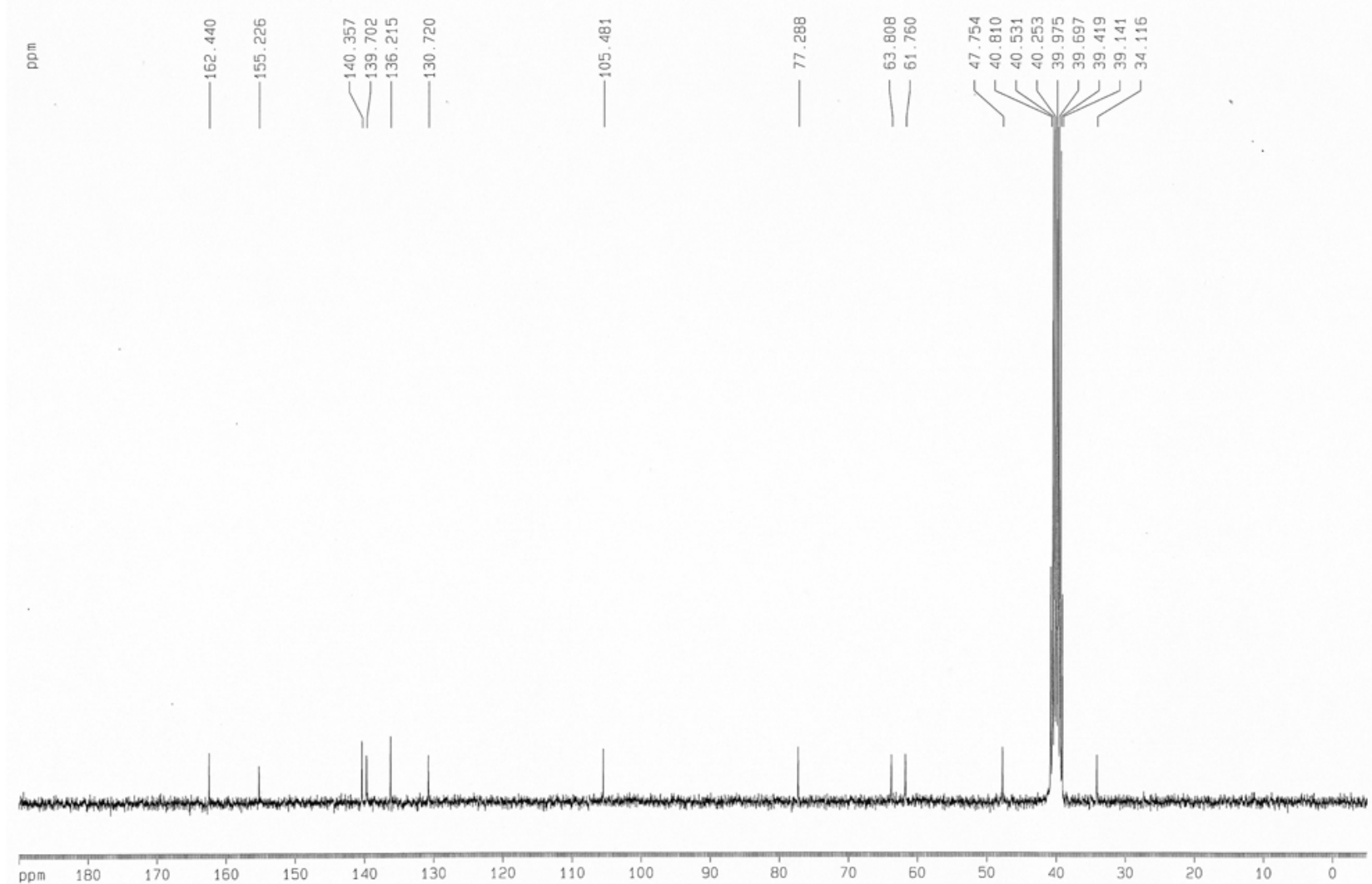

[ Mass Spectrum ]

Data : AHS280-d4 IVC-C12H14 IN302 Date : 16-Dec-2010 16:56

Sample: -
Note : -

Inlet : Direct Ian Mode : FAB

Spectrum Type : Normal Ion [EF-Linear]

$\begin{array}{ll}\text { RT : } 0.33 \mathrm{~min} & \text { Scant: }:(7.8) \\ \text { BP : } \mathrm{m} / 2391.2881 & \text { Int. : } 75.68\end{array}$

घp: maz 391.2081 346.2988 to 377.6251

.6261 Cut Level : $0.00 \%$
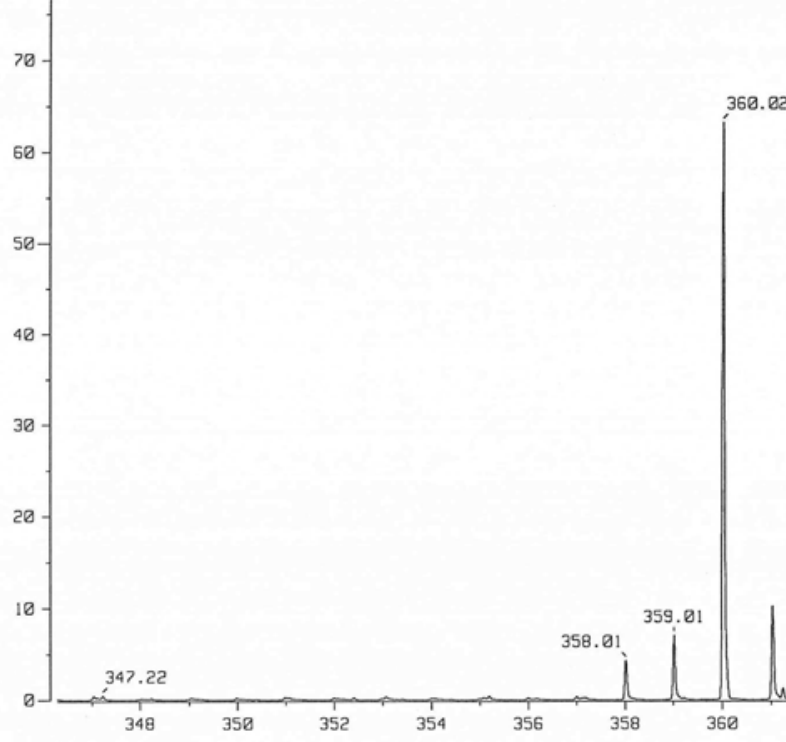

\section{อ. 82}


Radio-TLC and HPLC Analysis for Radioiodination of Carbocyclic d4IC (3)
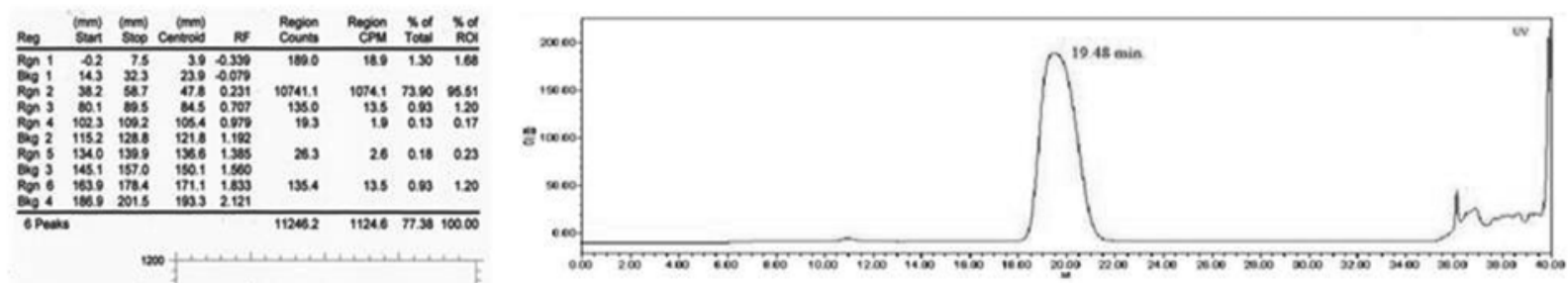

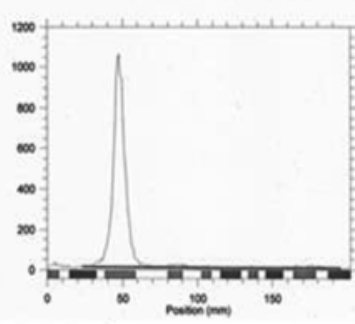

Radio-TLCanalysis

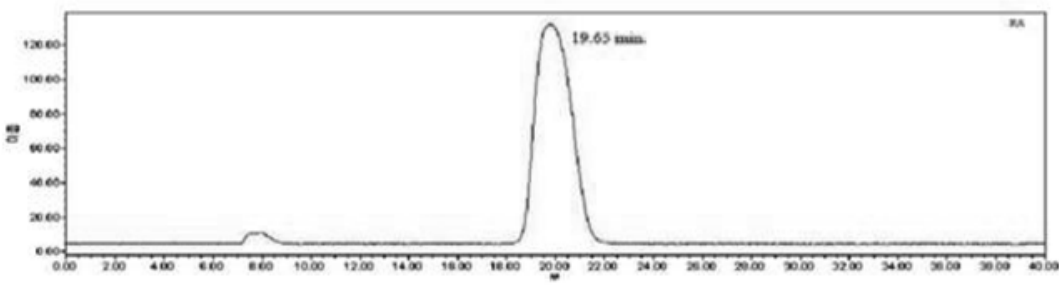

HPLC analysis

Radio-TLC and HPLC Analysis for Radioiodination of Carbocyclic d4IVC (4)

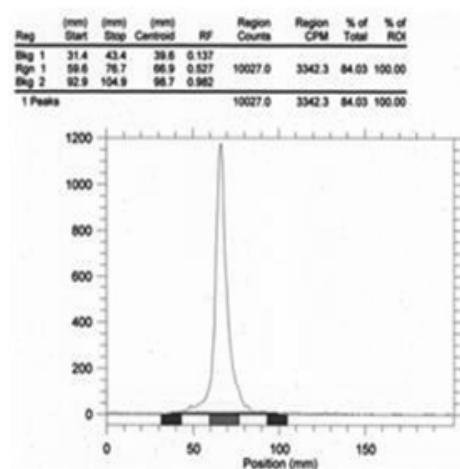

Radio-TLCanalysis

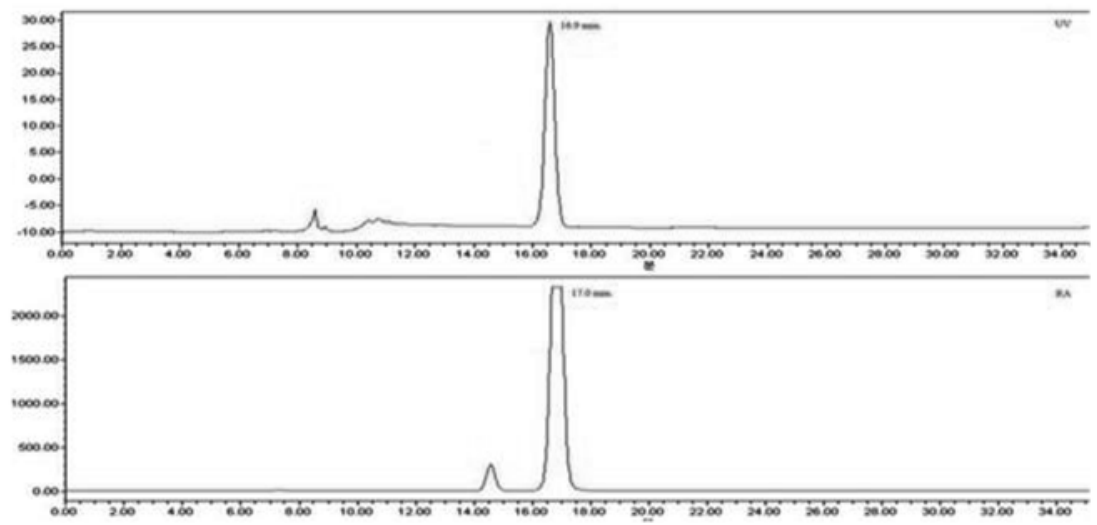

HPLC analysis 